\title{
The Effect of Internal Marketing on Turnover Intentions in Knowledge Workers in the IT Sector
}

\author{
Kessler Ladelsky Limor (Corresponding author) \\ The Graduate School of Business Administration. \\ Bar Ilan University, Ramat Gan, Israel \\ E-mail: Limor.kessler@biu.ac.il
}

Weisberg Jacob

The Graduate School of Business Administration.

Bar Ilan University, Ramat Gan, Israel.

E-mail: Jacob.weisberg@biu.ac.il

Received: Jan. 29, 2018 Accepted: Feb. 26, 2018 Online published: Mar. 7, 2018

doi:10.5296/ijhrs.v8i1.12550ＵRL: https://doi.org/10.5296/ijhrs.v8i1.12550

\begin{abstract}
This study suggests applying the concept of internal marketing to combat turnover intentions in knowledge workers in the IT sector. Internal marketing sees all employees as the firm's customers. The major hypothesis examined here is that when employees feel that a firm considers and treats them like customers, it increases employment commitment and reduces turnover intentions. A multivariate hierarchical regression analysis and structural equation modelling (SEM) incorporating demographic, personal, organizational and external variables were used to identify the unique contribution of internal marketing to turnover intentions. The findings showed a negative correlation between internal marketing and turnover intention that contributed significantly to the explained variance beyond the effects of other independent variables. These results are discussed in the light of their theoretical and practical implications and in particular that IT organizations should consider adopting internal-marketing practices to reduce turnover intention and hence voluntary turnover.
\end{abstract}

Keywords: voluntary turnover, turnover intention, IT, internal marketing, employee retention, knowledge workers 


\section{Literature and Hypotheses}

Employee turnover is costly to all firms and has significant negative effects on organizations (Cantrell \& Saranakhsh, 1991; DeMicco \& Giridharan, 1987; Denvir \& McMahon, 1992; Dyke \& Strick, 1990). It is considered to be an important issue for management in planning the labor force. Studies have examined the reasons underlying employee turnover, but to date there is no comprehensive way to explain and predict individual turnover intentions. Most factors discussed in the literature are related to psychological and sociological theories. By contrast, the study reported here suggests that internal marketing theory can lead to a better understanding of turnover intentions in the IT sector since key studies in this field have shown that the implementation of internal marketing has a negative effect on turnover intention (Ahmed \& Rafiq, 2002; Ballantyne, 2003; Cheng \& Whi, 2008; Wang, 2002; You, 2004).

Turnover in the IT profession has been the subject of considerable research (see, Pare and Tremblay, 2007). Most studies have examined intent to change jobs from an intra-individual perspective (Ang \& Slaughter, 2000). For instance, in a meta-analytic analysis of turnover antecedents over the last 100 years of research, Rubenstein, Eberly, Lee and Mitchell (2017) suggested that until recently the organizational context has generally been ignored in turnover research (Hom, Lee, Shaw and Hausknech, 2017). Hence, most meta-analyses in this category are new and discuss the pronounced effects of variables such as climate perception, organizational support, and rewards offered. However, no research has examined whether internal marketing itself can impact IT employees' turnover intentions and/or voluntary turnover. This study investigated the impact of internal marketing on a sample of 170 IT employees in the high-tech sector. The focus was on individual turnover intentions; i.e., voluntary turnover, which is defined as "voluntary cessation of membership in an organization, by an individual who receives monetary compensation for participation in that organization" (Hom \& Griffeth, 1995, p. 5; Rubenstein et al., 2017). The major finding recommendation is that high-tech firms should adopt internal-marketing strategies to alleviate turnover intention among their IT employees. Hom et al. (2017) noted that theorists should consider how different industries and their attributes (for example the high tech industry) that employ knowledge workers (e.g., engineers) might impact turnover intention differently from other industries/sector.

\subsection{Employee Turnover and Voluntary Turnover(VT)}

Turnover covers individuals' entry and exit in and out of an organization, though generally research has focused on employee turnover (Price, 1977). The most typical research classification is based on the nature of the turnover intention. For instance, intention to leave is classified as voluntary turnover as compared to involuntary turnover (Weisberg, 1990), which suggests that voluntary turnover is negative and dysfunctional for organizations (Pelled \& Xin, 1999).

Specifically, the damage to organizational efficiency (Hom \& Griffeth, 1995) caused by voluntary turnover is directly associated with the investment of time and money in the recruitment and training of new employees, and the high costs due to the loss of key 
personnel, in addition to the fact that it undermines the manufacturing process and its quality, and involves a period devoted to training new employees. Employee turnover also negatively affects those remaining in the organization, which can result in decreased job satisfaction, increased work load, and decreased organizational commitment, all of which also affect social coherence. "Functional turnover" is said to occur when a negatively evaluated employee voluntarily withdraws from the organization, whereas "dysfunctional turnover" occurs when a positively evaluated, contributing employee, whom the organization would prefer to retain, voluntarily withdraws (Blau \& Boal, 1987; Schwab, 1991). Abelson \& Baysinger (1984) referred to "dysfunctional turnover" as a situation where "the optimal balance between employee turnover costs and employee preservation costs is violated". In this respect, organizations aim to reach a state of optimal turnover that will balance out the involved costs. In terms of the organization, turnover of employees whom the organization prefers to preserve is expensive, but may not necessarily be detrimental to general organizational effectiveness. Furthermore, coping with turnover may be cheaper than preventing it. Hence, the extent of damage to the organization, if any, is determined by turnover extent, and the quality and commitment of the withdrawing employees (Dalton, Todor, \& Krackhardt, 1982; Muchinsky \& Morrow, 1980).

Turnover Intentions

Turnover intention is "a conscious and deliberate wilfulness to leave the organization" (Tett \& Meyer 1993, p. 262). It involves thinking about quitting one's current job and searching for another and is the best and most immediate predictor of turnover. It is a conscious, psychological motivation to leave one's job and hence withdraw from an organization (Tett \& Meyer 1993).

An employee will begin taking withdrawal-related actions only after becoming aware of his or her intentions and making the final decision. In other words, the intention to withdraw is a prerequisite to the actual steps toward withdrawal (Walsh, Ashford, \& Hill, 1985). In most studies conducted in the United States and Europe, declared withdrawal intention and actual withdrawal were found to be positively related [ranging from $r=.35$ (Mobley et al., 1978), and $\mathrm{r}=.85$ (Griffith et al., 2000)]. This logical linkage has been supported by empirical studies which have proven that the most effective voluntary turnover predictor is the intention to resign/voluntarily leave (Michaels \& Spector, 1982; Tett \& Meyer, 1993; Steel \& Ovalle, 1984). Other researchers have found turnover intention and actual turnover to be positively, strongly, and significantly related (March \& Simon, 1958; Krause et al., 1995; Brett \& Reilly, 1988; Motowidlo \& Lawton, 1984), a connection which was rationalized by these researchers as individual views toward a specific action. Economists focus more on actual turnover (Horn \& Gaertner, 2000; Griffeth, 2000; Mobley, Griffeth, et al., 1979) and suggest that changing jobs is based on the classic "cost/benefit" analysis where they expect the rewards they receive to exceed the costs. The rewards they expect to obtain can be both financial; e.g., a higher salary and better benefits, and psychological; e.g., better job security, more satisfying work, or a more pleasant work environment. Costs can also be financial and psychological. This context might explain why both young and more experienced employees are more likely than older employees to change jobs both in the public sector (Moynihan \& Landuyt, 2008) and in 
the marketplace as a whole (e.g., Farber, 1999). Moreover, younger employees are less likely to have found a good person-job match or a good person-organization fit, and thus they might be more willing to seek other jobs that use their skills and match their interests and values better (DelCampo, 2006; O'Reilly, Chatman, \& Caldwell, 1991). One study suggested that examining the turnover intention as a binary variable is less useful since at a certain time point it changes its status from remaining to withdrawing, and instead to view turnover intention as a variable indicating a process (Grissom \& Anderson, 2012).

Other researchers have rejected this assumption and maintain that while organizational withdrawal is a distinct, measurable behavioral action, turnover intentions merely represent a behavioral view which tends to be affected by several variables (Falkenburg \& Schyns, 2007; J. Mayfield \& M. Mayfield, 2008). Hence, the relationship should be examined under certain conditions (Fishbein \& Ajzen, 1975; Kirshenbaum \& Weisberg, 1990). Turnover intentions are not directly transformed into actual withdrawal, since environment-related factors such as the unemployment rate can moderate this relationship (Gerhart, 1990). Nevertheless, turnover intention is more commonly seen in the research literature as the most effective proxy withdrawal predictor (Tett \& Mayer, 1993; Modway et al., 1982; p.353; Blau, 2000; Hom et al., 2017). These findings thus underscore the importance of studies dealing with the turnover intention variable when attempting to understand and cope with turnover intentions and hence voluntary turnover.

The relationship between Commitment and Turnover intention

Employees join organizations with expectations about how the organization should operate and how they should be treated. When these expectations are not met, the employee's job satisfaction and organizational commitment levels fall and the employee may leave (Weisberg, 1990). Ever since the studies conducted by Mowday et al. (1982) and Porter, Steers, Mowday, and Boulian (1974), the factors accounting for the variance in degree of organizational commitment have been the subject of extensive investigation. Most of these studies have found that variability in organizational commitment within an organization can be significantly accounted for by the needs-provision variable. That is, organizational commitment depends upon the way in which employees' needs are met or not by the organization, and the prospects offered to employees to fulfill their organizational roles (e.g., Mayer \& Schooman 1993; Shore \& Martin, 1989). Commitment has been related to absenteeism and turnover, the two major types of withdrawal behavior. Studies have examined organizational commitment as a dependent variable (Earl \& Bright, 2007) and as an antecedent of work outcomes (e.g., Loi, Hang-Yue, \& Foley, 2006). The findings have consistently indicated a negative correlation between organizational commitment and turnover intention (e.g., Allen \& Meyer, 1990; Griffeth et al., 2000; Mathieu \& Zajac, 1990; Tett \& Meyer, 1993; Loi et al., 2006; Hom et al., 2017). This led to the following hypothesis:

Hypothesis 1: Organizational Commitment will be negatively associated with turnover intention among IT employees. 


\subsection{Organizational Variables}

Work values

According to value theory, employees have their own values and seek a value-focused workplace that is in harmony with these values. Thus, when the needs of internal customers change and the workplace (i.e., the needs provider) fails to adapt, these internal customers may become dissatisfied and consider terminating the relationship (Beverland et al., 2004). However, research shows that individuals who believe in work-related values and are working in an organization that encourages and promotes such an orientation have high levels of organizational commitment and report lower levels of turnover intention than other workers (Black, 1994; Hyde \& Weathington, 2006). Other studies have shown that organizations which are work value-oriented and whose employees are similarly oriented tend to have employees who exhibit high levels of commitment to the organization and lower levels of turnover intention (Hyde \& Weathington, 2006). This suggests that:

Hypothesis 2: Organizations that are perceived as promoting work values which are congruent with their employees' perceptions will have reduced levels of turnover intentions among their IT employees such that the more an organization is perceived as promoting work values to which its employees are similarly oriented, the less its IT employees will manifest turnover intentions.

\section{Internal Marketing}

Internal marketing is based on the notion of communication within an organization and considers employees as customers. Berry, Burke, and Hensel (1976) were probably the first to propose the concept of internal marketing. They developed the idea that because people are the most common service-delivery tools, their actions are likely to have significant effects on customer acquisition, retention, and migration. Internal marketing is defined as the process by which the organization hires, trains, and motivates its employees to provide satisfactory service to customers (Kotler, 1991). According to Ahmed and Rafiq (2003), internal marketing focuses on people inside organizational boundaries and emphasizes the fulfilment of employees' needs [(Ahmed and Rafiq, (2003)]. The two-fold positive effect of internal marketing consists of (a) building an atmosphere and environment in which workers are compelled to deliver their best efforts to the organization, and (b) "establishing, developing, and maintaining successful reciprocal exchange relationships within the organization through understanding and intimacy, trust and commitment" (Ahmed \& Rafiq, 2003, p. 1181). Gonroos (1981) suggested that each customer who is in contact with an employee should be considered a marketer who enables the development of a relationship that may result in additional sales and profits, as well as a more customer-conscious, market-oriented, and sales-minded work force. With regard to the needs of employees (i.e., internal customers), Kotler (1997) suggested that internal marketing should promote external marketing efforts.

In a similar vein, Higgins (1996, p. 480) argued that internal marketing enables a climate of trust within organizations. Hence the employee-employer relationship is seen as a service transaction. Dunne and Barnes (2000) extended this theory by arguing that the concept of 
internal marketing can be defined as the set of benefits that organizations provide to employees which includes motivation, job satisfaction, job involvement and organizational commitment. These are also the ingredients organizations want to design for their customers. It is also the basis for the approach to internal marketing that focuses primarily on benefiting employees. The overall premise is that this effort will benefit both the organization and its clients. Internal marketing can be regarded "as the process of initiating, maintaining, and developing the relationships between employees, their management, and the organization, for the purposes of creating superior value for customers" (Bell Simon \& Bulent, 2004, p. 113).

Implementing an internal marketing program helps to educate, stimulate, guide and lead employees to higher levels of performance and job satisfaction. One of the important outcomes of internal marketing is the increase in employees' commitment to the organization (Tansuhaj, Randall, \& McCullough, 1991; Hog, 1996). This, in turn, is expected to result in increased job satisfaction, improved job performance, and lower staff turnover (Jenkins \& Thomlinson, 1992; Mathieu \& Zajac, 1990; Schlessenger \& Haskett, 1991). Caruana and Calleya (1998) reported a significant relationship between internal marketing and affective commitment to an organization. There is also some empirical evidence for a significant relationship between internal marketing and business performance (Panigyrakis, 2009).

The major thrust of the internal marketing concept is to ensure that employees feel that management cares about them and that their needs are met. If these needs are not met, it will be difficult for employees to satisfy external customers. If employees' needs are met, they will be committed, cooperative, and enthusiastic about the organization (Ahmed \& Rafiq, 2002; Ballantyne, 2003). Internal marketing encourages employees to offer superb service to customers, since they appreciate their valuable contribution to the success of the business.

Although there is evidence that internal marketing as a managerial tool is fully understood and properly practiced by most organizations (Ahmed \& Rafiq, 2000), there are also negative effects. The core argument is that through a wide range of actions, practices, mistakes and premises, organizations can de-motivate rather than motivate their workforces, even when they are supposedly implementing well-designed internal-marketing strategies. Put differently, misconceived managerial actions aimed at motivating and engaging employees, management omissions, or inertia, as well as a lack of or weak internal-marketing policies (which may backfire) can generate undesirable perceptions among workers.

Vasconcelos (2011) dubbed this type of biased and/or dysfunctional organizational behavior internal de-marketing (ID) and suggested that it should be explored using a de-marketing-related approach. He defined ID as the "set of managerial actions, decisions, and behaviors - either consciously or unconsciously implemented - that are capable of triggering perceptions of frustration, disappointment, and dissatisfaction in work settings and that can potentially lead to decreased employee productivity and organizational performance" (Vasconcelos, 2011, p. 37). In its broadest sense, ID may result in organizational dysfunction and/or corporate malaise that may generate a lack of satisfaction, a lack of trust, and a lack of commitment among employees (Vasconcelos, 2011:37).

According to Vasconcelos (2011), ID is a consequence of organizations' failure to deal with 
their employees' needs, values, and expectations, and is a deficiency that stems from their internal marketing policies. These problems are either mismanaged or neglected by managers, although they try to put internal marketing into practice. Importantly, within this framework, it would be reasonable to expect that employees' morale would be lower. Damage can be complex and overwhelming, and even threaten the survival of the company, especially when human capital decides to voluntarily leave, taking its knowledge and skills to other organizations. Research in the IT sector has reported similar results. Wang (2002) discussed the relationship between internal-marketing practices and turnover intention in the entertainment industry. These findings indicated that there are five facets of internal-marketing practices that are significantly negatively correlated with turnover intention: education, training, management support, internal communication, external communication. He found that the more employees acknowledge the internal marketing practices that have been implemented; the less likely they are to consider leaving their jobs. You (2004), Schultz (2004), and Whi (2008) all validated this finding. This led us to formulate a single comprehensive hierarchal model to identify the multivariate effect of the independent variables on turnover intention. We hypothesized that:

Hypothesis 3: Internal marketing has a significant negative effect on turnover intentions.

This hypothesis goes beyond the effect of socio-demographic variables (i.e., marital status, age, education, and gender) and other independent variables, work values, commitment, and alternatives to one's current job. We thus posited that the more internal marketing-oriented the IT firm, the fewer the turnover intentions among its IT employees.

External Variables

Alternatives to the Current Job

Employees' turnover intentions are not sufficient in themselves to lead to their actual withdrawal. Actual withdrawal is influenced by environmental conditions: "Assessment of alternative prospects is defined as an individual's consideration of the rewards offered to him by various alternative organizations, while weighing the likelihood of acceptance to each" (Cartsen \& Spector, 1987). If an employee has not found an alternative job or is concerned that he or she may not find such a position, that employee may choose not to resign from his or her current job. Intentions to leave one's job will only be concretized when alternative employment is available and the worker is aware of that alternative and views it as favorable to his or her current position. The individual assesses the occupational environment and considers the benefits associated with switching to another job. In other words, the attractiveness of alternative jobs is assessed in relationship to one's current job (Mobley, Griffeth, Handand, \& Meglino, 1979). An employee's awareness of the costs (and rewards) involved in withdrawal from the current organization may affect his or her degree of organizational commitment or intention to stay in the organization (Allen \& Meyer, 1990; Van Dick, 2001).

Empirical studies confirm the assumption that an employee's intention to remain in his or her current job weakens as the number of available occupational alternatives grows. Yet, if the 
employee is unaware of the alternatives, not only will that employee's intention to remain in the organization increase, but, through a rationalization process, the employee will establish views that enhance his or her intention to remain in the current job (Mobley, 1982).

The assessment and perception of occupational alternatives include an employee's acknowledgement of available occupational alternatives, the likelihood of obtaining these alternative positions, and the benefits associated with the alternative as compared to the current job. Occupational alternatives may affect employees' turnover tendencies. The more an employee believes that alternative employment is readily available, the more turnover intention may exist or develop. This led to the fourth hypothesis:

Hypothesis 4: A growing perception of occupational alternatives will be positively related to turnover intentions.

Control variables

We attempted to neutralize demographic effects by holding the control variables constant. Researchers have found that the following demographic variables are associated with the turnover intentions variable and employee turnover behavior, and constitute important predictors: gender, age, position status (part time job vs. full time job), marital status, tenure, and education level (Brooke, 1986; Mobley, 1982; 1990; Baroudi and Igbaria, 1995; McBey \& Karakowsky, 2001; Igbaria and Chidambaram (1997); Borda, \& Norman, 1997; Hayes, 2006). However, the literature on the influence of demographic factors on turnover intentions has highlighted a number of conflicting findings. Some of the results are neither consistent nor conclusive (Chan and Morrison, 2000).

Five hypotheses were formulated to account for the control variables, as described below.

Gender

Women workers traditionally have been seen as having lesser attachment to the labor force than men. However, in their meta-analysis, Griffeth et al. (2000) reported only a negligible difference between men and women in terms of turnover (women were slightly more likely to leave their jobs than men). Joseph et al. (2007) found in their meta-analysis on IT employees that antecedents of turnover intentions in male IT employees had a stronger relationship with turnover intention than for female IT employees. Accordingly, we posited that:

H5.1: Female as compared to male gender will be negatively related to turnover intentions.

Age

Younger employees are more likely to take risks at the beginning of their careers. They are also more likely to accept positions that are below their abilities and expectations at the beginning of their career and move on to better jobs when these become available. Meta-analytic research supports the negative-age turnover intentions relationship (Griffeth et al. 2000). Accordingly, we hypothesized:

H 5.2 Employee age will be negatively related to turnover intention in IT employees. 
Marital Status

Cotton and Tuttle's (1986) meta-analysis review of turnover intention found a weak relationship with marital status. Married employees are typically found to be somewhat less likely to quit than people who are single (Cotton and Tuttle, 1986). The Joseph et al. (2007) meta-analysis of IT personnel found that marital status was negatively related to turnover intention in IT employees. Because married employees are likely to have greater financial burdens and need to consider their spouses' employment we hypothesized that:

H5.3: Married IT employees will be less likely to voluntarily leave their job as compared to unmarried IT employees.

Education

Higher levels of education are likely to increase individuals' turnover likelihood by increasing their opportunities (Joseph, Kok-Yee \& Christian, 2007). Therefore:

H5.4: Education will be positively related to turnover intentions in IT employees.

\subsubsection{Variables Effect on Internal Marketing}

Although there is scant literature on the topic, Schwartz (2006) reasoned that values are embedded in one way or another in the culture of each company and that company culture can be a competitive advantage that affects the development and continued implementation of internal-marketing practices. Kessler- Ladelsky (2014) found that a focus on work values that are important to IT employees in high-tech firms in Israel can enhance internal-marketing policies. Based on the literature above, we formulated the sixth hypothesis.

Hypothesis 6: Work values that are important to IT employees will positively affect internal marketing.

\section{The mediating effect of Commitment on Internal Marketing and Turnover Intention}

The marketing literature indicates that market orientation is an antecedent to organizational commitment. Jaworski and Kohli (1993) defined market orientation as consisting of three dimensions: intelligence gathering, intelligence dissemination, and responsiveness. Although these authors only used the affective dimension of commitment to measure organizational commitment, studies implementing the expanded organizational-commitment construct have indicated that market orientation is significantly related to the affective component of organizational commitment (Caruana et al., 1997). Gaertner (1999) posited that both work satisfaction and organizational commitment influence employees' intentions to leave (or not leave) their positions.

Caruana and Calleye (1998) pointed out that one of the important consequences of internal marketing is increased organizational commitment among employees (Tansuhaj et al., 1991). This, in turn, should result in increased job satisfaction, increased job performance, and lower staff turnover (Jenkins \& Thomlinson, 1992; Mathieu \& Zajac, 1990; Schlessenger \& Haskett, 1991). Other studies have shown that low levels of volunteer job satisfaction and organizational commitment are major determinants of volunteers' decisions to withdraw 
(Galindo-Kuhn \& Guzley, 2001; Miller et al., 1990; Pearce, 1983; Starnes \& Wymer, 2001). Organizational commitment has also emerged as a mediator (Yang \& Pandey, 2009) and affective commitment has been shown to mediate the relationship between human-resources systems and aggregate turnover (Way, 2002; Wilson \& Peel, 1991). Gardner et al. (2011) found that commitment acts as a partial mediator of turnover, supporting the existence of a mediating effect as suggested by Arthur (1994) and Way (2002). This finding, however, contradicts Huselid's (1995) claim that human-resources practices directly affect turnover (Gardner et al., 2011). This led to the seventh hypothesis.

Hypothesis 7: Organizational Commitment will mediate the relationship between internal marketing and turnover intentions.

The research model is depicted in Figure 1.

\section{Demographic}

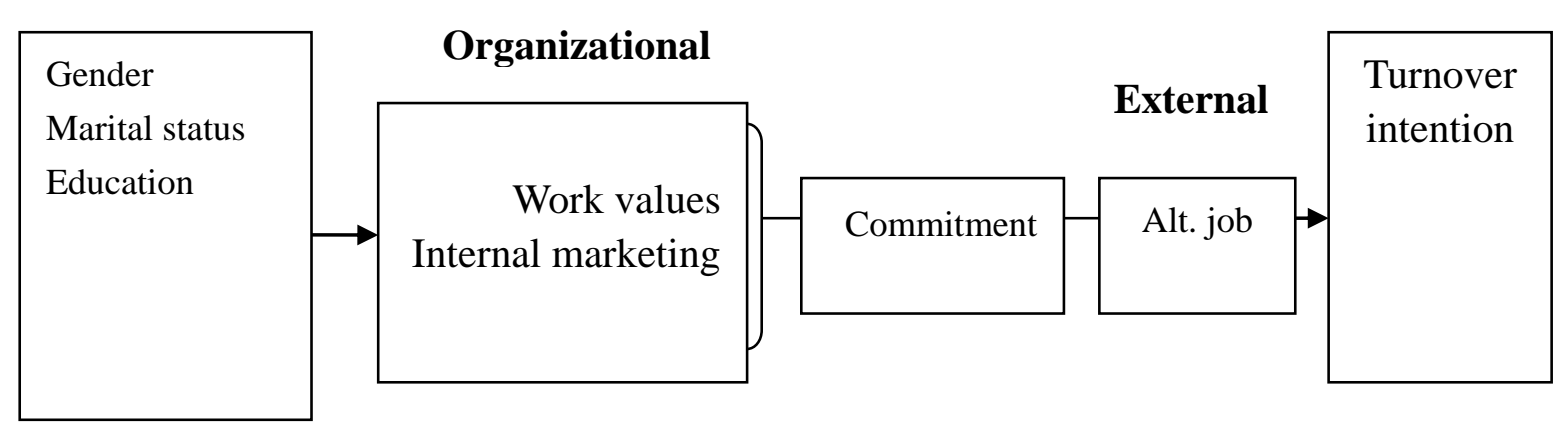

Figure 1. The effect of Demographic, Organizational, External and Internal Marketing Variables on Turnover Intention

\section{Method}

\subsection{Procedure Sample and Demographics}

The sample was composed of IT employees (i.e., programmers, developers, computer engineers, information systems engineers, software engineers, telecom developers, hardware engineers, software testers, practical engineers/technicians) in high-tech companies in Israel, who had worked in this sector for at least three years prior to the study. The population was made up of employees from high-tech companies with more than 50 employees (no start-up companies), including some global companies (such as Microsoft). The average age of the respondents was 39 (median 38) who had on average 7 years of technology experience. Forty percent of the sample was comprised of women. Ninety-four percent of the sample had an academic degree in technology including computer engineering, software engineering, computer science, etc. Eighty-six percent had management experience in the high tech sector. A pilot questionnaire (part of a longer questionnaire with a completion time of 25-45 min) was administered to 30 randomly selected IT employees. The distribution of the results (including skewness and kurtosis indices) and reliability indices showed that the data had a normal distribution and supported parametric tests. 
Following the pilot, 350 full questionnaires were distributed to three pools of IT workers: employees who were contacted through their employers (IT Company), employees contacted through personal connections, and employees contacted through courses in computer science or related fields they were taking in academic institutions. Specifically, questionnaires were sent by mail to 50 employees through their employers. The response rate for that group was 90\%. Questionnaires were also sent to 100 employees contacted through personal connections/networking. The response rate (via mail) for that group was $25 \%$. Two hundred questionnaires were delivered to second- and third-year undergraduate and postgraduate students enrolled in Computer Science, Business Administration with a specialization in computers, Software Engineering, and Computer Engineering who were already working in IT at high-tech companies. These questionnaires were handed out in class and by e-mail and $50 \%$ of them were completed and returned. The decision to include students in the research sample was based on the difficulty of obtaining approval from IT companies (domestic and international) to deliver questionnaires to their employees. The use of part of the workday to fill in the questionnaire involved high transaction costs for these companies due to the high hourly salaries of these workers. The 170 completed questionnaires were distributed and returned in two waves: November 2013 to December 2013 and February 2014 to July 2014. In both of them the same questionnaires and hence the same variables were measured. In the second wave we also accessed the managers of these employees and sent them the same questionnaires (that measured the same variables) to fill in as their employees. These questionnaires were returned up to three months later. The correlations between each pair of items (manager-employee) exceeded $r=.05$. The means for the employee and managers was $>.05)$.

\subsubsection{Measures}

Dependent variable. Turnover intention. In this study, we focused on turnover intention as a proxy for actual turnover and turnover intention as a valid predictor of turnover behavior. The Turnover Intention Questionnaire (based on Price, 2001) was used to measure the dependent variable. Three of the four items in this questionnaire were used to measure turnover intention (see Price, 2001).

The last item was dropped after the pilot run. A sample item is: "I would like to quit my job at [Company]". The scale ranged from 1 - strongly disagree to 5 - strongly agree. The internal consistency of this scale in Timmerman, Barger, Elsawy, and Mahmoud's (2003) study was 0.85 . The internal consistency (alpha) of the three-item scale used in the current study was 0.8. Two additional items that are accepted in the literature were added to the above-mentioned ones to measure employees' intention to voluntarily leave their employers. The first of these was "I intend to remain in my profession, but leave the organization at or before the end of this year". The second was "What are the chances that you will remain in the profession, but leave the organization at or before the end of the year?" Participants responded to this question using a 5-point scale: $1=$ no chance $;=100 \%$ chance. The first of these two items was deleted after the reliability test since without the deleted item, the scale showed the same reliability, indicating that these two items had the same meaning. The aim was to create an index that covered the entire world of content of turnover intention. The 
Cronbach's alpha for the remaining items was 0.9. The mean of the items was calculated and the new variable was called "turnover intention."

Independent variables. Two independent organizational-level variables were evaluated. The organizational-level independent variables were Work Values and Internal Marketing. Independent external variables were also evaluated. These external variables were Perceived Alternative Employment, commitment and demographic variables.

Work values. Organizational-level variable: Work values were measured using questions adapted from the Work Values Questionnaire (based on Elizur, Borg, Hunt, \& Beck, 1991). Twenty-four items were developed based on needs theories (Maslow, Alderfer, McClellend, Hetzberg, and Vroom Expectancy Theory) [(see Elizur et al., 1991)]. One additional question on ethics and integrity was added based on generational differences, so that a total of 25 items were used to identify the work values of the respondents. Respondents were asked to indicate "How important is it for you to have each of the following in your workplace" and the 25 values were listed. A six-point scale was used: $1=$ very unimportant; $2=$ unimportant; $3=$ somewhat unimportant $; 4=$ somewhat important $; 5=$ important $;$ and $6=$ very important . Items related to workplace values inquired about achievement at work, contribution to society, independence at work, job status, and recognition for doing a good job, and ethics and integrity. The internal consistency of the 25 item scale was 0.96 . After the reliability testing, the new variable was named Work Value. According to Elizur et al. $(1991 ; 1994)$, work values can be classified into three types: instrumental, affective, and cognitive. Instrumental work values pertain to desires and situations (Sagie, Elizur, \& Koslowsky, 1996). Affective work values pertain to emotionally satisfying outcomes, and cognitive work values pertain to a person's belief system about appropriate behavior practices (Sagie et al., 1996). All of the values were found to be highly reliable, with Cronbach's alpha coefficients in the range of .82-.91. The coefficients pertaining to the modalities were in the range of $.81-.84$.

Internal marketing. The internal-marketing instrument used in this study was taken from the index developed by Davis (2005) based on a review of the literature. The index included 25 questions that were answered on a seven-point Likert-type scale ranging from 1 (strongly disagree) to 7 (strongly agree). To evaluate this variable, we used eight items that fit the nominal definition of internal marketing in this research. These items were: "I feel my workplace treats me like a customer", "My personal needs are provided for by the workplace", "My workplace promotes the creation of customer relationships", "My workplace recognizes the fact that the employees are clients of the organization", "My workplace believes it is important to optimize the services/programs offered", "My place of work markets its 'products' (e.g., work conditions, benefits and rewards etc.)", "My workplace highlights the quality of service" and "My workplace makes employees aware of the quality of its products and services." The reliability of the scale in Davis's (2005) study was $\alpha=.87$. In the current study, the internal consistency for the eight-item scale (after pilot) was $\alpha=.8$. Following further means testing, a new variable called Internal Marketing was defined.

External variables. Alternative to Current Job. The Alternative to Current Work Questionnaire (based on Dennis \& Laker, 1991; Michael \& Spector, 1982) was used to 
evaluate perceived alternative jobs. This variable was measured by two items: (1) Intention to search for alternative employment that was developed by Dennis and Laker (1991). It was measured with a single item (each respondent was asked, "Within the next three months, do you intend to look for a different job with a different employer?"). This question was answered on a seven-point scale ranging from 1 (extremely likely) to 7 (extremely unlikely). (2) Perceived Ease of Movement / Alternative Employment was measured by asking respondents, "If you had to leave your job, how easy do you think it would be to find acceptable alternative employment?" The distribution of actual scores covered the entire 1-6 range, with a mean of 2.9 and a standard deviation of 1.4. This item was developed by Michaels and Spector (1982). The evaluation of alternatives was assessed by another (third) single item: "How attractive are other job possibilities (in this area) compared to your present job?" This item was answered on a five-point Likert scale ranging from 1 (much less attractive) to 5 (much more attractive) "than your present job". These two last items were subjected to a reliability test that revealed that the Cronbach's alpha coefficient for the two items was very low (.53). Therefore, we decided at the beginning to relate to each of these items separately. This decision was also based on the fact that each respondent expressed alternatives to current work differently in terms of perceived ease of movement or the elasticity of substitution. However, the second item (Perceived Ease of Movement) appeared to have greater validity than the first ("How attractive are other job possibilities?"), since it mentioned different alternatives in the labor market and outside the organization. In addition, it was positively and significantly related to turnover intention $(r=.204, p=.008)$, whereas the other was negatively but not significantly related to turnover intention $(r=-.123, p=.134)$. Finally, the last item also examined attractive alternatives to current work when the respondent was out of a job, whereas the current study was focused on individuals who were currently employed. The perceived ease of movement item had higher validity on the reliability test and the highest significant correlation with turnover. Thus, the first and second items were finally chosen to measure Alternative Employment with Perceived Ease of Movement. The reliability of the scale was $\alpha=0.7$.

Commitment to work. Commitment to Work was measured using questions adapted from the Commitment to Work Questionnaire (based on Allen and Meyer, 1990) which consists of a three-component model of organizational commitment. Five items from each of the revised six-item scales (Meyer, Allen, \& Smith, 1993) of affective, normative, and continuance commitment were used to measure organizational commitment. Affective/emotional commitment is the extent to which one feels an emotional attachment to an organization; normative commitment is the extent to which one perceives an obligation to remain with an organization, and continuance commitment is the extent to which one recognizes the costs associated with leaving an organization. Examples of these items include Q1: "I really feel as if [Company]'s problems are my own;" Q7:"I would feel guilty if I left [Company] now;" and Q13: "I feel that I have too few options to consider leaving [Company]" for affective, normative, and continuance commitment, respectively. Across various studies, the Cronbach's alpha coefficient values ranged from .77 to .88 for affective commitment, .65 to .86 for normative commitment and .69 to .84 for continuance commitment (Fields, 2002). In the current study, the internal consistencies of the different five-item scales (after the pilot 
study) were .9 for affective commitment, .8 for normative commitment, and .8 for continuance commitment, respectively. In order to create one variable from all the variables in the three scales, the first three item scales were reversed (i.e., Q2, Q3, and Q5). Then, in order to compute the mean of all the indices, reliability testing was carried out on all of them. After reliability testing, only items 1 and 4-10 were kept. Finally, a Cronbach's alpha value of 0.81 was obtained. After the reliability testing, a means test was performed for the remaining items and the new value was called Commitment Mean.

Demographic variables. Demographic factors can affect turnover intention in various ways. We thus controlled for gender, age, marital status, and education. Gender differences among high-tech professionals and their impact on turnover have been examined in previous studies. This variable was included in the hierarchical regression in light of the research findings reported in Baroudi and Igbaria (1995), Igbaria and Chidambaram (1997), Niederman and Sumner (2001), and Gallivan (2004). The item used to measure this variable was "What is your gender?" The answer scale was $0=$ male; $1=$ female. This was a demi-scale variable.

Age was included in light of the research findings reported in Guimaraes and Igbaria (1992), Igbaria and Siegel (1992), Moore (2000), Ahuja et al. (2002), and Gallivan (2004). The item used to measure this variable was "How old are you?" years. Marital status was included in the hierarchical regression in light of findings in Igbaria and Greenhaus (1992) and Moore (2000). The item used to measure this variable was "What is your marital status?" The answer scale was: $0=$ never married; $1=$ married without children; $2=$ married with children; 3 = separated $;=$ divorced $; 5=$ spouse $; 6=$ other. This was a demi-scale variable: $0=$ never married $; 1=$ all of the other options. Level of education completed was included based on Igbaria and Greenhaus (1992) and Moore (2000). The item used to measure this variable was "What level of education have you completed?" The answer scale was: $1=$ high school; 2 = higher education; 3 = bachelor's degree; $4=$ master's degree; $5=$ doctorate. It was coded as a demi-scale variable Non academic $=0$, academic . $=1$

\subsubsection{Self-Report Scales}

The data were collected from self-report questionnaires, which could lead to self-report bias. Several techniques for dealing with and mitigating response bias have been suggested in the literature. These include ensuring the anonymity of respondents, the use of a group (demographic-like) variable, sector affiliation, and assuring the participants that there are no right or wrong answers (Podsakoff, MacKenzie, Lee, 2003). Other researchers have compared studies that used only self-report measures with studies that included a behavioral measure. These show that the expected increase in correlations from the self-report measure is mitigated if one of the indices or variables is demographic-like (Crampton \& Wagner, 1994). Donaldson, Elisia, and Grant-Vallone (2002) concluded that a minimum of two data sources are needed to help rule out the validity threats of self-report bias and mono-method bias in business psychology research. Smith et al. (1983, as cited in Podsakoff \& Organ, 1986) avoided the same-source problem in their research by obtaining measures of satisfaction from half of the respondents in each department of the organizations that he studied. This approach was also suggested by Podsakoff et al. (2003). In this study, we minimized the risk of 
common method bias (CMB) by ensuring the confidentiality and anonymity of respondents, and informed the participants that there were no right or wrong answers. Originally, we used three objective data source engineers and their IT managers. The participants were not aware that these three sources were related and used in one study (as was done by Peltokorpi, Allen and Froese, 2015). Several reverse scored items were included to reduce acquiescence problems (Peltokorpi et al., 2015). We ensured that the respondents could not identify the conceptual model or statement that related to the dependent and independent variable and that these were not located close to each other. Additionally, multiple methods were used to measure the hypotheses (Wagner, 2011). Further, because our measures were embedded in an attitude survey and respondents were blind to our interest in turnover intentions, we had little reason to believe that self-selection bias could distort our results. Finally, we collected the data at least at three points in time over a 12- month period. Furthermore, CMB does not affect the intervention variables (for a similar tactic see Peltokorpi et al., 2015).

\section{Analysis}

The Kolmogorov-Smirnov test was used to confirm that the data were normally distributed. Skewness and kurtosis indices were found to be smaller than $+3 /-3$. Hence, it was concluded that the dependent variable was normally and symmetrically distributed and, therefore, parametric tests were conducted using hierarchical regression in which different sets of independent variables were entered. Additionally, an indirect script (Hayes \& Preacher, 2008) was used to assess the indirect effect. These procedures were carried out using SPSS 21. The validity of the theoretical model and the correlations among all of the variables were examined using Structural Equation Modelling (SEM) using AMOS 21 software.

\section{Results}

The main hypothesis of this study was that there would be a negative correlation between internal marketing and turnover intention beyond the influences of socio- demographic variables, personal variables, organizational variables and external variables. We combined all of our hypotheses into one comprehensive model to identify the multivariate effect of the independent variables on turnover intention and to show that internal marketing had a significant negative effect on turnover intention among IT employees in Israel, beyond the effects of all of the other independent variables that were entered into the regression model. The correlations between all of the independent variables were examined to test for multicollinearity. Examination of the correlations showed that there was no correlation that could interfere with the inclusion of these variables in the regression equation (i.e., the value of each correlation was not greater than 0.6 ), as can be seen in Table 1 below. 
Table 1. Means, Standard Deviations and Inter correlations among the Variables

\begin{tabular}{|c|c|c|c|c|c|c|c|}
\hline Variables & $M$ & $S D$ & $\begin{array}{c}1 \\
\text { Work } \\
\text { Values }\end{array}$ & $\begin{array}{c}2 \\
\text { Internal } \\
\text { marketing }\end{array}$ & $\begin{array}{c}3 \\
\text { Commitment }\end{array}$ & $\begin{array}{c}4 \\
\text { Alternative } \\
\text { employmen } \\
\mathbf{t}\end{array}$ & $\begin{array}{c}5 \\
\text { Turnover } \\
\text { intention }\end{array}$ \\
\hline Gender $^{\mathrm{a}}$ & .42 & .50 & -.02 & .02 & -.07 & -.10 & $-.16^{*}$ \\
\hline $\operatorname{Age}^{b}$ & 39 & 8.3 & .07 & -.01 & .14 & $.36^{* * *}$ & $.15^{\dagger}$ \\
\hline Marital status ${ }^{c}$ & .59 & .50 & .05 & -.10 & -.05 & -.10 & -.08 \\
\hline Education $^{\mathrm{d}}$ & .01 & .08 & $-.35^{* * *}$ & .04 & -.10 & -.07 & .04 \\
\hline Work values & 5.3 & .69 & 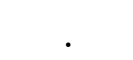 & $.4^{* * *}$ & $.3^{* * *}$ & $-.16^{* *}$ & . \\
\hline $\begin{array}{l}\text { Internal } \\
\text { marketing }\end{array}$ & 4.7 & 1.3 & $.4^{* * *}$ & . & & & \\
\hline Commitment & 4.3 & 1.2 & $.3^{* * *}$ & $.29^{* * *}$ & . & .06 & . \\
\hline $\begin{array}{l}\text { Alternative } \\
\text { employment }\end{array}$ & 3.1 & 1 & $-.2^{*}$ & -.05 & & . & \\
\hline $\begin{array}{l}\text { Turnover } \\
\text { intention }\end{array}$ & 2.6 & 89. & -.09 & $-.34^{* * *}$ & $-.48^{* * *}$ & .02 & . \\
\hline
\end{tabular}

Note. $N=170 .{ }^{\mathrm{a}} 0=$ male $; 1=$ female. ${ }^{\mathrm{b}}$ "how old are you? $" \mathrm{c} 0=$ Single $1=$ All other.

${ }^{\mathrm{d}} 0=$ Non academic $1=$ Academic

$\dagger p<0.10 * p<0.05 . * * p<0.01 . * * * p<0.001$

In the hierarchical regression, the demographics were entered in the first stage, the organizational variables Work Values and Internal Marketing were entered in the second stage, and the external variable Alternative to Current Work was entered in the third stage and also the variable Commitment.

We also tested the hypotheses via SEM using AMOS. The structural equation model (Figure 2) had an acceptable overall goodness-of-fit (Kline, 2010): NFI $=.883$; CFI $=0.970$. In addition, the following indices were found: REMSA $=0.04$ and $\chi^{2}=31.66$ with $p=0.168(d f$ =37). Concerning the hierarchical regression, in the first stage, when age, marital status, education, and gender were entered into the model, none of these demographic variables predicted turnover intention except gender $(\beta=-0.14 ; p<.05)$. In the second stage, in which the organizational variables were entered, the effect of gender on turnover intention decreased but became non- significant $(\beta=-0.12 p>.05)$. In the third stage, the relationship remained negative but strengthened and again became significant $(\beta=-0.13 ; p=0.04)$. Thus, Hypothesis 5.1 (which posited that turnover intentions in female IT employees would be negatively related to turnover intentions in male IT employees) was confirmed in the hierarchical regression. Additionally, in the second stage, in which the organizational variables were entered into the regression, the effect of marital status on turnover intention remained negative but increased and became significant $(\beta=-0.17 ; p=.03)$. By contrast, in the third stage in which the external variables were entered into the regression, the effect of 
marital status on turnover intentions increased and became more highly significant $(\beta=-0.22$; $p=.00$ ). Thus, Hypothesis 5.3 (which hypothesized that married IT employees would be less likely to voluntarily leave their job than single IT employees), was confirmed in the hierarchical regression. The findings indicated that there were fewer turnover intentions among women who were not single (divorced, married, widows). In the hypothesis testing under SEM, the only correlation between the demographic variables and turnover intention was a significant negative relationship between gender and turnover intention $(\beta=-0.17 ; p<$ 0.01). Specifically, there were fewer turnover intentions among women than among men. All the other correlations between the demographic variables and turnover intentions were indirect and insignificant. This finding was not consistent with the results of our hierarchical regression. Thus Hypothesis 5.2 (which posited that employees' age would be negatively related to turnover intention among IT employees) and Hypothesis 5.4 (which posited that education would be positively related to turnover intentions among IT employees) were not confirmed. On the other hand, Hypothesis 5.3 (that married IT employees would be less likely to voluntarily leave their job compared to unmarried IT employees) was partially confirmed.

In the second stage, the macro-level organizational variables Work values and Internal Marketing were entered into the regression. Work values were found to have a positive nonsignificant effect on turnover intention $(\beta=.10 ; p=.24)$. Specifically, the congruence between IT employees' values and the organization's values did not relate to and did not affect their intention to leave or voluntarily leave their jobs in the high- tech company. In other words, Hypothesis 2 (which posited that organizations that were perceived as promoting work values which were congruent with the employees' perception would show reduced levels of turnover intentions among their IT employees) was not confirmed in the hierarchical regression analysis. Thus we evaluated the correlation using the SEM analysis by AMOS. In the SEM analysis, work values did have a significant positive direct effect on turnover intentions $(\beta=0.15 ; p=0.03)$. Specifically, it was found that the congruence between IT employees' values and the organization's values increased turnover intentions. That is, in this phase, Hypothesis 2 (which assumed that organizations that were perceived as promoting work values which were congruent with employees' perceptions would show reduced levels of turnover intentions among their IT employees) was not confirmed in the SEM analysis either.

Afterwards, still in the second stage, the variable Internal Marketing (actually a macro-level organizational variable) was also entered into the regression. This was the main variable that we wanted to examine since we were interested in the relationship between internal marketing and turnover intention beyond the effects of the other independent variables. The results showed that when there was little or no Internal Marketing, there was more turnover intention $(\beta=-0.40, p=0.000$ ). This correlation was highly significant. Thus, Hypothesis 3 was supported. A bootstrap analysis in which there were 1000 runs of the model yielded the same results at the same level of significance. In the SEM analysis, Hypothesis 3 was also confirmed $(\beta=-0.22 ; p=0.00)$. Internal Marketing had a negative effect on turnover intention; this finding is congruent with the results of the hierarchical-regression analysis. 
The results of the hypothesis testing are presented in Table 2 and Figure 2.

Table 2. Hierarchical Regression Models for Predicting Turnover Intentions

\begin{tabular}{lccc}
\hline Variable & Model 1 & Model 2 & Model 3 \\
\hline Gender $^{\mathrm{a}}$ & $-.14^{*}$ & -.12 & $-.13^{*}$ \\
$\mathrm{Age}^{\mathrm{b}}$ & .11 & .05 & .10 \\
Marital status $^{\mathrm{c}}$ & -.11 & $-.17^{*}$ & $-.22^{* * *}$ \\
Education $^{\mathrm{d}}$ & & & .07 \\
Work values $_{\text {Internal Marketing }}$ & & .10 & .10 \\
Commitment & & $-.40^{* * *}$ & $-.29^{* * *}$ \\
Alternative Job & & & $-.49^{* * *}$ \\
$R^{2}$ & $.06^{*}$ & $.18^{* * *}$ & .01 \\
$\Delta R^{2}$ & $.06^{*}$ & $.12^{* * *}$ & $.39^{* * * *}$ \\
Adjusted $R^{2}$ & $.03^{*}$ & $.15^{* * *}$ & $.21^{* * *}$ \\
F change & $* 2.4$ & $12.7^{* * *}$ & $.36^{* * *}$ \\
\hline
\end{tabular}

Note. $N=170$. The hierarchical method was Stepwise and Enter. Standardized coefficients (B) were presented.

${ }^{\mathrm{a}} 0=$ Male; $1=$ Female ${ }^{\mathrm{b}}$ how old are you? " $0=$ Single $1=$ All other $\quad{ }^{\mathrm{d}} 0=$ Non academic $1=$ Academic .

$\dagger p<0.10 * p<0.05 . * * p<0.01 . * * * p<0.001$.

As can be seen in Table 2, Internal Marketing had a significant negative effect on turnover intention among IT employees beyond the effects of socio-demographic variables, personal variables, organizational variables, and external variables. To summarize, hypothesis 3 (which posited that internal marketing would have a significant negative effect on turnover intentions) was supported in all the analyses. In the third stage, the external variable Alternative employment (Job) was entered into the regression. This variable represents labor turnover flexibility, to the extent that there are perceived alternatives to one's current job. We found that the existence of perceived alternatives in the labor market to the IT employees' current work did not affect turnover intention $(\beta=.01 ; p>.05)$. Specifically, Hypothesis 4 , which assumed that increasing perceptions of occupational alternatives would be positively related to turnover intentions, was not supported by the results of the hierarchical-regression analysis. In the SEM analysis, Hypothesis 4 was confirmed $(\beta=.17 ; p=.01)$, suggesting that the more alternatives there are to the current jobs of IT employees in high-tech companies, the greater their level of turnover intention. This finding was not supported by the results of the hierarchical regression analysis. In this stage, Commitment was also entered into the regression. The findings showed that Commitment was strongly associated with turnover intention, in that as Commitment decreased, turnover intention increased ( $\beta=-.49 ; \mathrm{p}=.00)$. Thus Hypothesis 1 which stated that commitment would be negatively associated with 
turnover intention among IT employees was confirmed in the hierarchical regression. The SEM analysis also supported this finding $(\beta=-.46 ; p=.00)$.

Furthermore, when commitment was entered into the regression, the effect of internal marketing on turnover intention remained significantly negative but decreased more (from $\beta$ $=-.40 ; \mathrm{p}=.00$ to $\beta=-.29 ; \mathrm{p}=.00$ ) possibly due to the contribution of the explained variance $\left(\Delta R^{2=} .21 ; \mathrm{P}=.00\right)$ of commitment on turnover intention. This also reinforces the findings related to Hypothesis 3 showing that Internal Marketing had a negative effect on turnover intention.

In this phase when commitment was entered into the regression, the effect of work values on turnover intention increased (from $\beta=.10 ; \mathrm{p}=.24$ to $\beta=.18 ; \mathrm{p}=.02$ ) and became significant, as was found in the SEM analysis. This sheds light on Hypothesis 2 which posited that organizations that are perceived as promoting work values which are congruent with the employees' perceptions should show reduced levels of turnover intentions among their IT employees. Thus the SEM findings and the relationships were reexamined.

Specifically, in the SEM analysis conducted to examine Hypothesis 2, we found the set of relations that underlies this association. On the one hand, Work Values had a significant positive direct effect on turnover intentions $(\beta=0.18 ; p<0.01)$. However, simultaneously in the SEM the correlation between Work Values and turnover intention appeared to be mediated by internal marketing. The variable Work Values was positively correlated with Internal Marketing $(\beta=0.48 ; p<0.001)$ and negatively correlated with turnover intentions $(\beta$ $=-0.22 ; p<0.001)$. Thus, in order to verify this association, a script designed to examine indirect mediation was run (SPSS Macro indirect examination for multiple mediation). The analysis adhered to the criteria stipulated in Preacher \& Hayes, 2008 (that rely on the stages/procedures recommended by Baron and Kenny, 1986 and Kenny 2016). The finding showed that the coefficient between Work Values and turnover intention before mediation was $\beta=-11 ; p=.26$ and that the coefficient between Work Values and turnover intention after mediation was $\beta=.07 ; \mathrm{p}=.47$. A Sobel test indicated mediation $(\mathrm{Z}=-3.6 ; p<.001 / p=.00)$. This procedure was also recommended by Baron \& Kenny (1986; Kenny et al. 1998). Next, a bootstrap analysis was conducted (for further confirmation) in which there were 1000 runs of random samples of the model, and the confidence interval of the mediator was calculated. The findings showed that the confidence interval was between -.08 and -.37 , thus confirming mediation because the confidence interval did not include 0 at the level of $95 \%$, or at the level of $p<0.05$. Thus, Internal Marketing significantly mediated the correlation between Work Values and turnover intention. However, this mediation effect requires further explanation since there was an increase and not a decrease in the coefficients between the variables in path c (before the mediation) in comparison to path c' (after mediation). The increase in the coefficient between the variables ranged from (-.11) before mediation to (+.07) after mediation. This increase of (+.12) was significant. However, there was no significant correlation before or after mediation. We thus examined the existence of this mediation in terms of the literature.

According the mediation model requirements in Baron and Kenny's (1986) method, there 
must be a significant correlation between the predictor variable $\mathrm{X}$ and the dependent variable $\mathrm{Y}$ (Path c) in the first stage. In the second stage, the predictor variable $\mathrm{X}$ must correlate significantly with the mediating variable $\mathrm{M}$ (Path a). In the third stage the dependent variable Y must correlate significantly with the mediator variable $\mathrm{M}$ (Path b) and in the fourth stage the association between the predictor variable $\mathrm{X}$ and the dependent variable $\mathrm{Y}$ (path $\mathrm{c}^{\prime}$ ) must be significantly less after controlling for the mediator. According to these classical mediation model requirements, the first stage [(which stipulates that there must be a significant correlation between the predictor variable $\mathrm{X}$ and the dependent variable $\mathrm{Y}$ (path c)] has to exist and the fourth stage [which stipulates that the association between the predictor variable $\mathrm{X}$ and the dependent variable $\mathrm{Y}$ ] must be significantly less after controlling for the shared variance between the mediator and dependent variable (path c). That is, Path c' must be significantly less than Path c.

However, Kenny et al. (1998) argued that the first of these conditions is not necessary. They and other researchers such as MacKinnon et al. (2002), Shrout \& Bolger (2002) and Frazier et al. (2004) described several situations in which mediation may occur in the absence of a significant relationship between the predictor and dependent variable. Although Baron and Kenny (1986) specifically enumerated the fourth step, other researchers testing mediation recommend satisfying the first three conditions alone. MacKinnon et al. (2002, 2007, 2009) referred to the general three-step approach as the causal steps method. However, Baron and Kenny (1986) clearly indicated that additional procedures are required to examine the magnitude of the mediating effect and its statistical significance. According to Frazier et al. (2004, in Mallinckrodt, Abraham and Wei, 2006) mediation should be tested by more than one method to determine the mediator. Otherwise we would conclude that the indirect effect of Work Values on turnover intention as mediated by internal marketing was not statistically significant since $M$ mediates the association between $\mathrm{X}$ and $\mathrm{Y}$ even if the total effect $(c)$ is not significant.

In fact, there is a relatively large consensus among statisticians that the total effect $(c)$ should not be used as a 'gatekeeper' for tests of mediation (e.g., Hayes, 2009; Shrout \& Bolger, 2002). The causal steps approach, though historically popular, has been widely replaced by methods of testing for mediation that are more statistically powerful, make fewer assumptions about the data, and are more logically coherent such as macro script (Hayes \& Preacher, 2008). According to these authors, the steps should not be stated in terms of statistical significance because trivially small coefficients can be statistically significant with large sample sizes and very large coefficients can be non-significant with small sample sizes. In the hierarchical regression, the effect of work values on turnover intention was $B=.19(p<.000)$. The SPSS Macro used to examine mediation showed that the total effect (the correlation coefficient before entering the mediator internal marketing) emerged as negative $(B=-.11)$. In other words, the net effect was originally negative and not positive, as can be seen in the hierarchical regression. To summarize, the results of the mediation analysis and the literature would appear to indicate that Hypothesis 2 was supported. Thus, congruence between IT employees' values and high- tech company values decreased turnover intention and hence voluntary turnover. 


\section{Macrothink}

The results for Hypothesis 6 indicated that Work Values which are important to IT employees positively affect internal marketing. In order to predict internal marketing, a hierarchical regression was run via SPSS. The relevant demographics were entered in the first stage of the hierarchical regression, and the organizational variable work values was entered in the second stage. The data analysis showed that work values had a significant positive effect on internal marketing $(\beta=0.48, p=0<0.001)$. Specifically, the more a high tech firm is focused on the values that are important to its IT employees, the more internal marketing will be adopted and used. The SEM analysis also revealed a strong positive correlation between work values and Internal Marketing $(\beta=0.48, p<0.001)$ as can be seen in Figure 2.

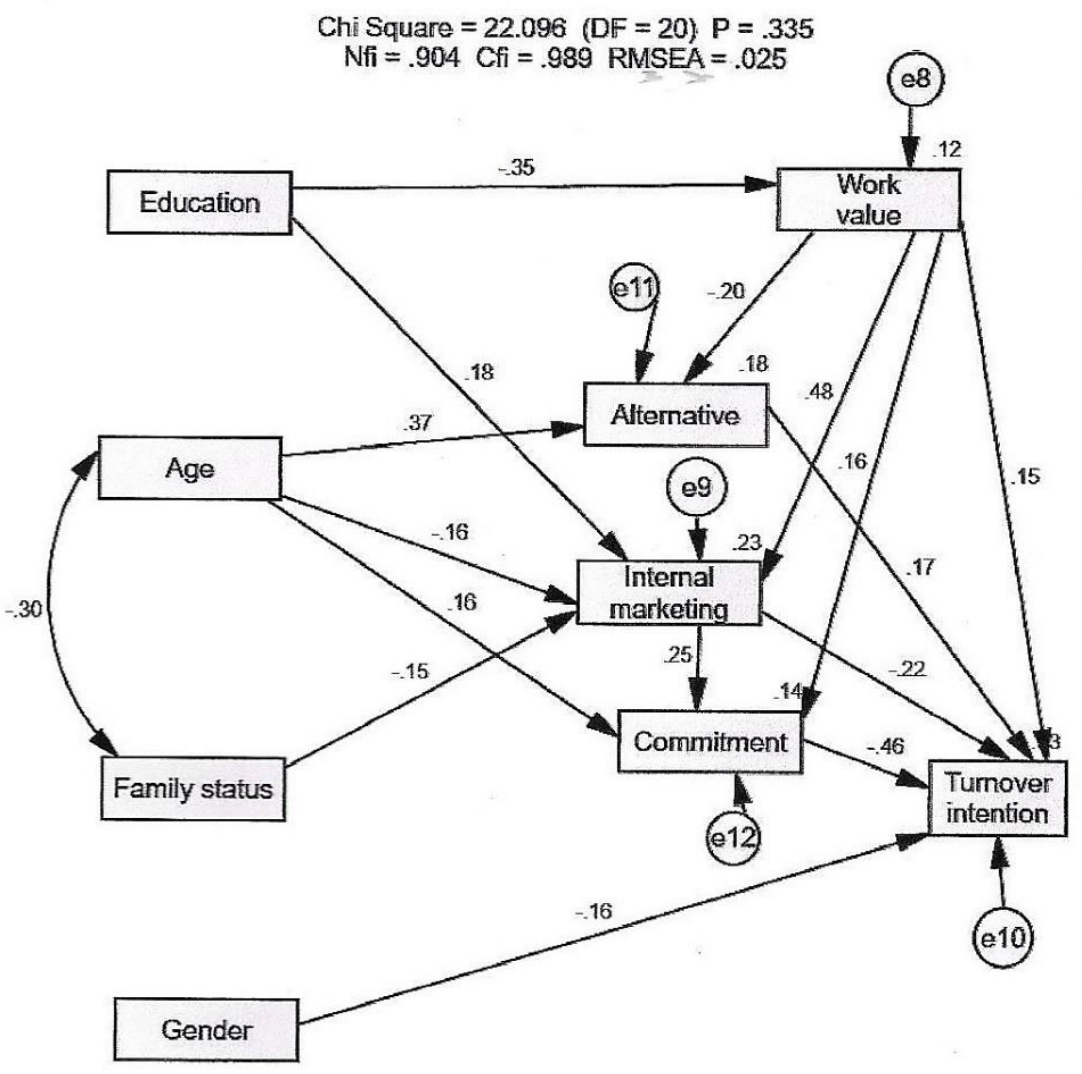

Figure 2. The SEM research model run in AMOS.

Thus, to summarize, Hypothesis 6 stating that work values that are important to IT employees positively affect internal marketing was supported by the results of the hierarchical regression analysis and by the SEM analysis. Additionally, when we examined which variables were associated with Internal Marketing, as compared to which variables were associated with turnover intention, we found that the work values variable was correlated with both Internal Marketing and turnover intention in the same direction.

The results for Hypothesis 7 indicated that Commitment mediated the relationship between internal marketing and turnover intentions. A script to evaluate indirect mediation was run (as 
described by Preacher \& Hayes, 2008 based on Baron and Kenny, 1986) to test the hypothesis that Commitment mediates the relationship between internal marketing and turnover intention. The analysis showed that commitment partially mediated this relationship. For path a, the effect of internal marketing (IV) was positive and significant $(\beta=.28, p=.000)$ on turnover intention (DV). A direct effect was found between commitment (the mediator) and turnover intention (DV) (path b). The commitment (the mediator) effect was negatively significant $(\beta=-.31, P=.000)$ on turnover intention (DV). A total effect (path $c$ ) was found for internal marketing (IV) on turnover intention (DV) $[\beta=-.24 ; p=.000]$. Finally, there was a direct effect (path $c^{\prime}$ ) of internal marketing (IV) on turnover intention (DV) [ $\left.\beta=-.16 ; p=.002\right]$. In sum, all the conditions listed in Baron and Kenny's (1986) method to test for mediation as well as the Preacher \& Hayes stipulations (2008) were satisfied and the hypothesis that commitment mediates the relationship between internal marketing and turnover intentions was supported. The Sobel test for mediation was significant $(Z=-2.5 ; p<0.01)$ showing that Commitment mediated the correlation between Internal Marketing and turnover intention.

Additionally, we found that the confidence interval ranged from 0.01 to 0.11 . Since this interval did not include 0 , the mediation was statistically significant at a confidence level of $95 \%$, or at the level of $p<0.05$. An additional, indirect examination of this mediation was conducted (also in SPSS) using the bootstrap method. This method produced 1000 random samples from the data and calculated the confidence interval of the mediator. The bootstrap analysis showed that the mediating effect of the variable Commitment had a confidence interval of 0.01-0.11. As that interval did not include 0 , it was significant at a confidence level of $95 \%$. We also computed the VAF, which determines the size of the indirect effect in relation to the total effect (i.e., direct effect indirect effect): $\mathrm{x} 1 * \mathrm{y} 1 / \mathrm{x} 1 * \mathrm{y} 1+\mathrm{c} 0$. When the VAF has an outcome between $20 \%$ and $80 \%$, a partial mediation can be expected (Hair, Hult, Ringle and Sarstedt, 2014). The value obtained in this study was located within this interval; the VAF for the indirect effect was $54 \%$. Hence Commitment can be seen as a significant partial mediator, thus supporting Hypothesis 7.

\section{Discussion}

The current work attempted to shed light on the effects of internal marketing on turnover intention among IT employees, independent of socio- demographic, personal, organizational, and external variables. The results of the hierarchical-regression analysis and the SEM analysis were very similar, except for the findings regarding Hypothesis 4 which posited that increasing perceptions of occupational alternatives were positively related to turnover intentions. In the SEM analysis of this hypothesis, we found a positive relationship between the perceived existence of alternatives to the current jobs of IT employees and turnover intention. However, this finding was not replicated in the hierarchical-regression analysis.-

The findings regarding Hypothesis 1 which posited that Commitment would be negatively associated with turnover intention among IT employees indicated that commitment reduced turnover intention. This conclusion is in line with the findings reported in Allen and Meyer (1990), Mathieu and Zajac (1990), Tett and Meyer (1993), and Griffeth et al. (2000) as well that indicate a decrease in turnover intention (as reported by Loi et al., 2006). This 
relationship has not been previously researched in the high- tech industry in Israel.

Concerning Hypothesis 2, which stated that organizations that are perceived as promoting work values which are congruent with their employees' perceptions would show reduced levels of turnover intentions among their IT employees, we found that the more IT employees believe that the high- tech company in which they work indeed focuses on work values that are important to them, the less they will develop turnover intentions, as was posited by value theory (Locke 1976; Beverland et al., 2004). Research shows that individuals with high levels of organizational commitment report lower levels of turnover intention than other workers (Black, 1994; Hyde \& Weathington, 2006). However, this correlation was not found initially. In both the hierarchical regression and in the SEM analysis we found that work values had a positive effect on turnover intention. This finding appeared illogical and more complex. The SEM revealed that work values increased internal marketing policies and the latter decreased turnover intention. Thus, we tested whether there was an intervening variable in this correlation via in-depth analysis (based on Baron and Kenny, 1986; Preacher and Hayes 2008; Hayes 2013). It was found that internal marketing partially mediated the relationship between work values and turnover intention in engineers in high tech companies in the IT sector (Kenny 2016). Thus, beyond providing additional support for earlier findings, this study also shows that internal marketing plays an important mediating role between work values and turnover intention among IT employees in the high tech sector.

The main aim of this study was to examine the effect of internal marketing on turnover intention among IT employees (Hypothesis 3). Internal marketing is defined in the literature as an approach that views the employee as an internal customer (Woodruff, 1997) and views processes inside the organization as a client-supplier relationship (Berry, 1984; Foreman \& Money, 1995). According to this model, if the internal customer is satisfied, so is the external customer (George, 1977). Managers and organizations that do not encourage the implementation of an internal marketing policy (ID situations) might prompt employees to develop frustration, anger, and grief. These feelings may affect employee productivity and their contributions to organizational performance (see Vasconcelos, 2011). The lack of an internal-marketing policy might lead to a decrease in employee satisfaction and undesirable behavior (Ahmed and Rafiq, 2000) to the point of the development of turnover intention (Cheng \& Whi, 2008; Schlessenger \& Haskett, 1991; You, 2004). Our focus was on individual turnover intention. The findings indicate that in order to reduce turnover intention, high tech companies (in which IT employees are crucial to the achievement of organizational objectives) should adopt and implement internal marketing. This means the creation of a customer-supplier relationship in which everyone in the IT firm is viewed as providing and/or receiving services from other employees and departments. Internal marketing views employees as internal customers with needs that the organization has to fulfil. An internal-marketing policy creates an environment that encourages employees to meet the demands and goals of the organization, helps motivate employees, creates long-term commitment to the organization, and furthers the achievement of organizational goals. This policy helps create internal customer satisfaction, which serves to create external customer satisfaction with the organization and its products. An internal-marketing policy can decrease 
and prevent turnover intention among IT employees who work in high tech companies.

Regarding the findings concerning Hypotheses 5 that examined socio- demographic variables on turnover intention, only Hypothesis 5.1 was confirmed. This indicated that female Israeli IT employees are less likely than their male peers to voluntarily leave their jobs in high-tech companies. This finding contrasts with data reported in Igbaria and Chidambaram (1997). This difference may be attributed to differences in the employee populations sampled in the studies.

Hypothesis 6 posited that work values that are important to IT employees positively affect internal marketing. In both the hierarchical regression analysis and the SEM analysis, we found that the more an organization adopts work values, the stronger its internal marketing. This provides additional support for earlier findings [Schwartz (2006); Kessler Ladelsky (2014)]. However we also found that work values increased internal marketing and hence decreased the turnover intentions of IT employees in high-tech companies in Israel. Finally consistent with Hypothesis 7 which posited that Commitment mediates the relationship between internal marketing and turnover intentions, we found that Commitment significantly partially mediated the relationship between Internal Marketing and turnover intention. This supports the findings in Wilson \& Peel (1991), Arthur (1994), Way (2002), Young and Pandey (2009) and Gardner et al. (2011).

Two correlations in the SEM models deserve attention. The effect of education on work values: The results of the SEM showed that education level had a negative effect on the perception of the importance of work values $(B=-.35 ; \mathrm{p}<.001)$. Specifically, the higher the level of education of an IT employee, the less s/he perceives work values as important. Wanxian, Li et al. (2007) found that more education was related to higher work values (Chi-square $=12.41, \mathrm{p}<0.05$ ). However, research shows (for example, Chai and Mo, 1997; Huang, 2004) that the effect of education on work values is different for employees with a bachelor's degree as compared to higher degrees, and among knowledge workers as compared to others. This result seems to be consistent with findings in Baron and Kenny (1986) who suggested that the relationship might be moderated by level of education.

The effect of work values on alternatives to the current job: The results of the SEM showed that the perception of the importance of work values among employees negatively affected their perceptions of alternatives to current work $(B=-.20 ; p<.001)$ : the more employees perceived work values as important in the workplace the less they perceived there were alternatives to their current job in the labor market. Work values were found to have significant effects on job choice decisions (Judge\& Bretz, 1992). According to Maglino and Ravlin (1987), values are thought to influence the selection and interpretation of external stimuli, thereby affecting the organization of behavioral choices or the formulation of alternatives (e.g., Rokeach, 1973). Values, therefore, should be related to the interpretation of stimuli as well as to actual decision-making behavior and also to perceived alternatives to one's current job (Maglino and Ravlin, 1987). These studies examined the effect of work values on perception and decision making. Their results suggested that "values are hierarchically organized in memory, and that people will find opportunities, within the 
context of their duties, to apply their dominant value in uncertain situations" (p. 672). This approach implies that individuals have a preference for ordering or ranking values to which they refer when making behavioral choices and also in their perceptions of alternatives to their job. Finally, Vroom (1966) found that individuals made job choices that are consistent with their work goals. Some of these goals are value-laden, suggesting that individuals make job decisions to decide whether there are alternatives to their current work, based in part on their perception of work values (Cable and Judge, 1996).

\section{Theoretical Contribution}

The current study makes several contributions to theory and research. The findings presented here provide specific answers to the main hypotheses posited above. These findings indicate that internal marketing has a significant effect on turnover intention beyond the effects of the other variables that were included in the hierarchical regression. Different theoretical explanations for this phenomenon have been put forward in the literature based on psychological, sociological, economic, managerial, and marketing theories. Research suggests that internal marketing affects the turnover intention of IT employees who are internal customers of the companies at which they are employed. That is to say, internal marketing is critical to achieving the organization's objectives, just like external marketing, and is a significant tool for managing IT employees as customers and achieving the organization's objectives (i.e., increasing the firm's profitability). Marketing theories are also helpful in explaining employee retention and the prevention of turnover intentions by creating employee commitment mechanisms. These theories, which include a consumer-behavior model, are not included in the classical literature on this issue. However, we believe that they should be considered. Their inclusion in this work allows us to make a unique contribution to the turnover literature, since our study analyzed the turnover intention of IT employees in high-tech companies as internal customers. When these employees are satisfied with the organization's attitude toward them (due to the adoption and implementation of internal-marketing policies), they are committed to the organization and show loyalty to it. When they are not satisfied, they develop the intention to leave.

Another contribution relates to the indirect effects found here on turnover intention. This has several key theoretical implications. We found that the work values focus of an IT firm which is congruent with their IT employees' values has a negative effect - not directly on turnover intention - but through internal marketing. Specifically, this suggests that management should implement an internal marketing policy such that the values of the firm are congruent with those of its IT employees, which will hence decrease turnover intention.

The third contribution has to do with the intermediary correlation between internal marketing and turnover intention. We found that commitment partially mediates this relationship. Gardner et al. (2011) found that commitment acts as a partial mediator of turnover, supporting the existence of a mediating effect, as suggested by Arthur (1994) and Way (2002). However in addition to what was found in previous studies about this potential mediator, this study provides initial evidence for the process flow that internal marketing strengthens the commitment of IT employees and reduces turnover intention among engineers in high tech 
firms. This finding contributes to the body of knowledge on the relationship between internal marketing and turnover intentions.

\section{Limitations and Avenues for Future Research}

A number of limitations need to be addressed in this study. This research was carried out on a sample of 170 IT employees. This sample size may undermine attempts at external validation. The sample size was limited by the lengthy approval processes needed before the high tech companies would distribute the survey to their IT employees. Since the hourly wage of IT employees is relatively high, taking time off the job to fill in the questionnaire was expensive for their employers. To overcome this limitation, the hypotheses and model were also tested on 140 IT managers in IT companies (where permission to administer the questionnaires was only secured with the assistance of the Research Unit of the Israel Ministry of Economy). Second, while the methodology and the statistical tests were chosen carefully, latent biases may still exist.

In future studies, a behavioral indicator of turnover should be used to minimize common-method bias. Future studies should reexamine the effect of internal marketing on turnover intention within the larger IT population in Israel, as well as globally in different high tech companies and under different economic circumstances (e.g., during periods of growth and expansion), in order to compare results. This should be done to generalize the findings to other countries and validate the research model as an international or cross-country model. Finally, although we collected turnover data from 3 different employee sources and from different, objective sources with a lag of 3 months from their managers, future research should attempt to replicate our findings using data collected with a wider variety of methods.

\section{Practical Implications}

From a practical point of view, these findings provide new insights into turnover intentions and human capital retention, which may be useful for human resources and organizational development managers, consultants, and senior technology managers (CTO, VP Technology, etc.). These findings may provide these professionals with a new approach (i.e., internal marketing) for handling and preventing turnover intention that is applicable to all organizations and, specifically, to high tech companies. The results show that IT employers in particular need to invest in adopting an internal marketing policy and creating commitment among engineers in order to successfully prevent turnover. The management of high tech companies should invest in adopting work values that are in harmony with their IT employees' values to lessen turnover intention and hence voluntary turnover.

\section{Conclusion}

Our results suggest that the implementation of an internal-marketing policy creates an opportunity to improve the quality of processes (such as internal services) within an organization (Prasad \& Steffes, 2002). Internal marketing is a tool that harnesses employees' commitment and creates an environment in which every employee acts as a customer. This increases staff retention (i.e., reduces voluntary turnover). Moreover, companies can also reap 
additional benefits from the implementation of internal-marketing policies since these policies are considered catalysts for the achievement of organizational objectives.

\section{Acknowledgements}

The authors thank Prof. Peter Bamberger, Coller School of Management, Tel Aviv University, Israel for his useful remarks on this manuscript. The authors also thank Prof. Avraham (Rami) Friedman, School of Business Administration, the Hebrew University, Jerusalem, Israel for his useful remarks on this manuscript.

The authors are indebted to Mr. Beni Fefferman, Director of Research and Financial Administration at the Israel Ministry of Economy for providing the data for this research.

The authors are grateful to the Graduate School of Business Administration of Bar Ilan University, Israel that made it possible to write this manuscript as part of the first author's post-doc.

The authors are grateful to the Beit Berl Academic College research authority Israel for funding the final editing of the paper.

\section{References}

Abelson, M. A., \& Baysinger, B. D. (1984). Optimal and dysfunctional turnover: Toward an organizational level model. Academy of Management Review, 9, 331-341. https://doi.org/10.2307/258446

Ahmed P. K., \& Rafiq, M. (2003). Commentary: Internal marketing issues and challenges. European Journal of Marketing, 37, 1177-1186. https://doi.org/10.1108/03090560310498813

Ahmed, P. K., \& Rafiq M. (2000). Advances in the internal marketing concept: Definition, synthesis and extension. Journal of Services Marketing, 14, 449-463. https://doi.org/10.1108/08876040010347589

Ahmed, P. K., \& Rafiq, M. (2002). Internal marketing: Tools and concepts for customer-focused management. Amsterdam, the Netherlands: Butterworth-Heinemann. https://doi.org/10.1016/B978-0-7506-4838-7.50006-5

Ahuja, M. K. (2002). Women in the information technology profession: A literature review, synthesis and research guide. European Journal of Information Systems, 11, 20-34. https://doi.org/10.1057/palgrave.ejis.3000417.

Allen, N. J., \& Meyer, J. P. (1990). The measurement and antecedents of affective, continuance and normative commitment to the organization. Journal of Occupational Psychology, 63, 1-18. https://doi.org/10.1111/j.2044-8325.1990.tb00506.x

Andersen, S., \& Grisson, J. A. (2012). Why superintendents turn over. American Educational Research Journal, 49, 1146-1180. https://doi.org/10.3102/0002831212462622

Arthur, J. B. (1994). Effects of human resource systems on manufacturing performance and turnover. Academy of Management Journal, 37, 670-687. https://doi.org/10.2307/256705 
Ballantyne, D. (2003). A relationship-mediated theory of internal marketing. European Journal of Marketing, 95, 1242-1260. https://doi.org/10.1108/03090560310486979

Baron, R. M., \& Kenny, D. A. (1986). The moderator-mediator variable distinction in social psychological research: conceptual, strategic, and statistical considerations. Journal of $\begin{array}{lllll}\text { Personality } \quad \text { and } & \text { Social } & \text { 1173-1182. }\end{array}$ https://doi.org/10.1037/0022-3514.51.6.1173

Baroudi, J. J., \& Igbaria, M. (1995). An examination of gender effects on career success of information systems employees. Journal of Management Information Systems, 11, 181-201. https://doi.org/10.1080/07421222.1994.11518055

Bell, S. J., \& Bulent, M. (2004). When customers disappoint: A model of relational internal marketing and customer complaints. Journal of the Academy of Marketing Science, 32, 112-126. https://doi.org/10.1177/0092070303261467

Berry, L. L. (1984). The employee as customer. In C. Lovelock (Ed.), Services marketing (pp. 271-278). Englewood Cliffs, NJ: Prentice-Hall.

Berry, L. L., Hensel, J. S., \& Burke, M. C. (1976). Improving retailer capability for effective consumerism response. Journal of Retailing, 52(3), 3-14.

Black, B. (1994). Culture and effort: British and Irish work-related values and attitudes. International Journal of Human Resource Management, 5, 875-892. https://doi.org/10.1080/09585199400000070

Blau, G. (2000). Job, organizational and professional context antecedents as predictors of intent for intervolve work transitions. Journal of Vocational Behavior, 56, 330-345. DOI:10.1006/jvbe.1999.1718

Blau, G., \& Boal, K. (1987). Conceptualizing how job involvement and organizational commitment affect turnover and absenteeism. Academy of Management Review, 12, 288-300. https://doi.org/10.5465/AMR.1987.4307844

Borda, R. G., \& Norman, U. (1997). Testing a model of absence and intent to stay in employment: A study of registered nurses in Malta. International Journal of Nursing Studies, 34, 375-384. https://doi.org/10.1016/S0020-7489(97)00030-8

Brett, M. J., \& Reilly, A. H. (1988). On the road again: Predicting the job transfer decision. Journal of Applied Psychology, 73, 614-620. https://doi.org/10.1037/0021-9010.73.4.614

Brooke, P. B. (1986). The determinants of employee absenteeism: An empirical test of a causal model. Journal of Occupational Psychology, 62, 1-19. https://doi.org/10.1111/j.2044-8325.1989.tb00473.x

Cable, D. M., \& Judge, T. A. (1996). Person-organization fit, job choice decisions, and organizational entry. Organizational Behavior and Human Decision Processes, 67, 294-311. https://doi.org/10.1006/obhd.1996.0081

Carsten, J. M., \& Spector, P. E. (1987). Unemployment, job satisfaction, and employee 
turnover: A meta analytic test of the Muchinsky model. Journal of Applied psychology, 72, 374- 381. https://doi.org/10.1037/0021-9010.72.3.374

Caruana, A., \& Calleya, P. (1998). The effect of internal marketing on organizational commitment among retail bank managers. The International Journal of Bank Marketing, 16, 108-116. https://doi.org/10.1108/02652329810213510

Caruana, A., Ramaseahan, B., \& Ewing, M. T. (1997). Market orientation and organizational commitment in the Australian public sector. International Journal of Public Sector Management, 10, 294-303. https://doi.org/10.1108/09513559710180556

Chai, H., \& Mo, J. H. (1997). A perspective of the enterprise employees' work values. Journal of Zhongshan University, 6, 42-82.

Chan, E., \& Morrison, P. (2000). Factors influencing the retention and turnover intentions of registered nurses in a Singapore hospital. Nursing and Health Science, 2, 113-121. https://doi.org/10.1046/j.1442-2018.2000.00046.x

Cotton, J. L., \& Tuttle, J. M. (1986). Employee turnover: a meta-analysis and review with implication of research. Academy of Management Review, 11, 55-70. https://doi.org/10.5465/AMR.1986.4282625

Crampton, S. M., \& Wagner, J. A. (1994). Percept-percept inflation in micro organizational research: An investigation of prevalence and effect. Journal of Applied Psychology, 79, 67-76. https://doi.org/10.1037/0021-9010.79.1.67

Dalton, D. R., Todor, W., \& Krackhardt, D. (1982). Turnover overstated: The functional taxonomy. The Academy of Management Review, 7, 117-123. https://doi.org/10.5465/AMR.1982.4285499

Davis, J. P. (2005). The effects of internal marketing on service quality within collegiate recreational sport: A quantitative approach (Doctoral dissertation). Retrieved from ProQuest Central. (Order No. 3176903)

DelCampo, R. G. (2006). The influence of culture strength on person-organization fit and turnover. International Journal of Management, 23, 465-469.

DeMicco, F. J., \& Giridharan, J. (1987). Managing employee`s turnover in the hospitality industry. Journal of FIU Hospitality Review, 5(2), 26-32.

Donaldson, S. I., \& Grant-Vallone, J. E. (2002). Understanding self-report bias in organizational behavior research. Journal of Business and Psychology, 17, 245-260. https://doi.org/10.1023/A:1019637632584

Dunne, P. A., \& Barnes, J. G. (2000). Internal marketing: A relationship and value creation view. In R. J. Varey \& B. R. Lewis (Eds), Internal marketing: Directions for management (pp. 192-220). London: Routledge. https://doi.org/10.4324/9780203207352.ch12

Earl, J. K., \& Bright, J. E. H. (2007). The relationship between career decision status and important work outcomes. Journal of Vocational Behavior, 71, 233-246. 
https://doi.org/10.1016/j.jvb.2007.05.003

Elizur, D., Borg, I., Hunt, R., \& Beck, I. M. (1991). The structure of work values: A cross-cultural comparison. Journal of Organizational Behavior, 12, 21-38. https://doi.org/10.1002/job.4030120103

Fairchild, A. J., \& MacKinnon, D. P. (2009). A general model for testing mediation and $\begin{array}{lllll}\text { moderation } & \text { effects. } & \text { Prevention } & \text { Science, } & 10,\end{array}$ https://doi.org/10.1007/s11121-008-0109-6

Falkenburg, K., \& Schyns, B. (2007). Work satisfaction, organizational commitment and withdrawal behaviors. Management Research News, 30(10), 708-723. https://doi.org/10.1108/01409170710823430

Farber, H. S. (1999). Alternative and part-time employment arrangements as a response to job loss. Journal of Labor Economics, 17, S142-S169. https://doi.org/10.1086/209946

Fields, D. L. (2002). Taking the measure of work: A guide to validated scales for organizational research and diagnosis. Thousand Oaks, CA: Sage. https://doi.org/10.4135/9781452231143

Fishbein, M., \& Ajzen, I. (2005). Theory-based behavior change interventions: Comments on hobbies and Sutton. Journal of Health Psychology, 10, 27-31. https://doi.org/10.1177/1359105305048552

Foreman, S., \& Money, A. (1995). Internal marketing: Concepts, measurement and application. Journal Marketing Management, 11, 755-768. https://doi.org/10.1080/0267257X.1995.9964388

Frazier, P. A., Tix, A. P., \& Barron, K. E. (2004). Testing moderator and mediator effects in counseling psychology research. Journal of Counseling Psychology, 51, 115-134. https://doi.org/10.1037/0022-0167.51.1.115

Gaertner, S. (1999). Structural determinants of job satisfaction and organizational commitment in turnover models. Human Resource Management Review, 9, 479-493. https://doi.org/10.1016/S1053-4822(99)00030-3

Galindo, K. R., \& Guzley, R. M. (2001). The volunteer satisfaction index: Construct definition, measurement, development, and validation. Journal of Social Service Research, 28, 45-68. https://doi.org/10.1300/J079v28n01_03

Gallivan, M. J. (2004). Examining IT professionals' adaptation to technological change: The influence of gender and personal attributes. The Data Base for Advances in Information Systems, 35(3), 28-49. https://doi.org/10.1145/1017114.1017119

Gardner, T. M., Wright, P. M., \& Moynihan, L. M. (2011). The impact of motivation, empowerment, and skill enhancing practices on aggregate voluntary turnover: The mediating effect of collective affective commitment. Personnel Psychology, 64, 315- 350. https://doi.org/10.1111/j.1744-6570.2011.01212.x 


\section{Macrothink}

International Journal of Human Resource Studies

ISSN 2162-3058

2018, Vol. 8, No. 1

Gerhart, B. (1990). Voluntary turnover and alternative job opportunities. Journal of Applied Psychology, 75, 467-476. https://doi.org/10.1037/0021-9010.75.5.467

Griffeth, R. W., Horn, P. W., \& Gaertner, S. (2000). A meta-analysis of antecedents and correlates of employee turnover: Update, moderator test, and research implications for the next millennium. Journal of Management, 26, 463-488. https://doi.org/10.1177/014920630002600305

Grönroos, C. (1981) Internal marketing: An integral part of marketing theory. In J. H. Donnelly \& W. R. George (Eds), Marketing of services: Proceedings of the American Marketing Association, Services Marketing Conference (pp. 236-238). Chicago, IL: American Marketing Association.

Grönroos, C. (1985) Internal marketing: Theory and practice: In T. M. Bloch, G. D. Upah \& V. A. Zeithaml (Eds,), Services marketing in a changing environment (pp. 41-47). Chicago, IL: American Marketing Association.

Guimaraes, T., \& Igbaria, M. (1992). Determinants of turnover intention: Comparing IC and IS. Information Systems Research, 3, 207-303. https://doi.org/10.1287/isre.3.3.273

Hair, J. F., Hult, G., Ringle, C., \& Sarstedt, M. (2014). A primer on partial least squares structural modeling (PLS-SEM). Thousand Oaks, CA: Sage.

Hayes, A. F. (2009). Beyond Baron and Kenny: Statistical mediation analysis in the new $\begin{array}{llll}\text { millennium. } & \text { Communication } & \text { Monographs, } & \text { 76, }\end{array}$ https://doi.org/10.1080/03637750903310360

Hayes, M. (2006). On the efficiency of fair trade. Review of Social Economy, 64, 447-468. https://doi.org/10.1080/00346760601024419

Higgins, S. H. (1996). Towards taming the labor-management frontier: A strategic marketing framework. Journal of Business Ethics, 15, 475-485. https://doi.org/10.1007/BF00380367

Hom, P. W., \& Griffeth, R. W. (1995). Employee turnover. Cincinnati,OH: South-West College.

Hom, P. W., Lee, T. W., Shaw, J. D., \& Hausknecht, J. P. (2017). One hundred years of employee turnover theory and research.

Huang, S. S. (2004). A study on the relationship of work values and organizational commitment for QC personnel (Unpublished doctoral dissertation). JI Nan University, Guangzhou, China.

Huselid, M. A. (1995). The impact of human resource management practices on turnover productivity and corporate financial performance. Academy of Management Journal, 38, 635-672. https://doi.org/10.2307/256741

Hyde, R. E., \& Weathington, B. L. (2006). The congruence of personal life values and work attitudes. Genetic, Social, and General Psychology Monographs, 132, 151-190. https://doi.org/10.3200/MONO.132.2.151-192 
Igbaria, M., \& Chidambaram, M. (1997). The impact of gender on career success of information systems professionals. Information Technology and People, 10, 63-86. https://doi.org/10.1108/09593849710166165

Igbaria, M., \& Siegel, S. R. (1992). The reasons for turnover among information systems personnel. Information and Management, 321-331. https://doi.org/10.1016/0378-7206(92)90014-7

Jaworski, B. J., \& Kohli, A. K. (1993). Market orientation: Antecedents and consequences. Journal of Marketing, 57(3), 53-70.

Jenkins, M., \& Thomlinson, P. P. (1992). Organizational commitment and job satisfaction as predictors of turnover intentions. Management Research News, 15(10), 18-22. https://doi.org/10.1108/eb028263

Joseph, D., Ng, K. Y., Koh, C., \& Ang, S. (2007). Turnover of information technology professionals: A narrative review, meta-analytic structural equation modeling, and model development. MIS Quarterly, 31, 547-577. https://doi.org/10.2307/25148807

Judge, T. A., \& Bretz, R. D. (1992). The effects of work values on job choice decision. Journal of Applied Psychology, 77, 261-271. https://doi.org/10.1037/0021-9010.77.3.261

Kenny, D. (2016). Mediation. Retrieved September 25, 2016 from: http://davidakenny.net/cm/mediate.htm

Kenny, D. A., \& Judd, C. M. (2014). Power anomalies in testing mediation. Psychological Science, 25, 334-339. https://doi.org/10.1177/0956797613502676

Kenny, D. A., Kashy, D. A., \& Bolger, N. (1998). Data analysis in social psychology. In D. Gilbert, S. T. Fiske, \& G. Lindzey (Eds.), Handbook of social psychology (4 ${ }^{\text {th }}$ ed., Vol. 1, pp. 233 - 265). New York: McGraw-Hill.

Kessler, L. L. (2014). Causes and conditions affecting employees' voluntary turnover intentions: An internal marketing approach - the case of hi-tech employees in Israel (Unpublished doctoral dissertation). BBU University, Berlin,Germany.

Kirshenbaum, A., \& Weisberg, J. (1990). Predicting worker turnover: An assessment of intent on actual separations. Human Relations, 43, 829-847.

https://doi.org/10.1177/001872679004300902

Kline, R. B. (2010). Principles and practice of structural equation modeling ( ${ }^{\text {rd }}$ ed.). New York, NY: Guilford Press.

Kotler, P. (1991). Marketing management: Analysis, planning, implementation and control. ( $7^{\text {th }}$ ed.). Englewood Cliffs, NJ: Prentice-Hall.

Kotler, P. (1997). Marketing management: Analysis, planning, implementation and control. ( $9^{\text {th }}$ ed.). Englewood Cliffs, NJ: Prentice-Hall.

Laker, D. R. (1991). Job search perceptions of alternative employment and turnover. The 
Journal of Applied Business and Research, 7(1), 6-15. https://doi.org/10.19030/jabr.v7i1.6254

Locke, E. A. (1976). The nature and causes of job satisfaction. In M. Dunette (Ed), Handbook of industrial and organizational psychology (pp. 1297-1349). Chicago, IL: Rand McNally College Publishing.

Loi, R., Ngo, H. Y., \& Foley, S. (2006). Linking employees' justice perceptions to organizational commitment and intention to leave: The mediating role of perceived organizational support. Journal of Occupational and Organizational Psychological, 79, 101-120. https://doi.org/10.1348/096317905X39657

MacKinnon, D. P., \& Fairchild, A. J. (2009). Current directions in mediation analysis. Current Directions in Psychological Science, 18, 16-20. https://doi.org/10.1111/j.1467-8721.2009.01598.x

MacKinnon, D. P., Chondra, M. L., Jeanne, M. H., Stephen G. W., \& Virgil, S. (2002). Acomparison of methods to test mediation and other intervening variable effects. Psychological Methods, 7, 83-104. https://doi.org/10.1037/1082-989X.7.1.83

MacKinnon, D. P., Fairchild, A. F., \& Fritz, M. S. (2007). Mediation analysis. Annual Review of Psychology, 58, 593-614. https://doi.org/10.1146/annurev.psych.58.110405.085542

Mallinckrodt, B., Abraham, T., Wei, M., \& Russel. D. W. (2006). Advances in testing the statistical significance of mediation effects. Journal of Counseling Psychology 53, 372-378. https://doi.org/10.1037/0022-0167.53.3.372

March, J. G., \& Simon, H. A. (1958). Organizations (2 ${ }^{\text {nd }}$ ed.). Oxford, England: Blackwell.

Mathieu, J. E., \& Zajac, D. M. (1990). A review and meta-analysis of the antecedents, correlates and consequences of organizational commitment. Psychological Bulletin, 108, 171-194. https://doi.org/10.1037/0033-2909.108.2.171

Mayer, R. J., \& Schooman, F. (1993). An integrative model of organization trust. Entrepreneurship Theory and practice, 17, 5-15.

Mayfield, J., \& Mayfield, M. (2008). The creative environment's influence on intent to turnover: A structural equation model and analysis. Management Research News, 31(1), 4156. https://doi.org/10.1108/01409170810845949

McBey, K., \& Karakowsky, L. (2001). Examining sources of influence on employee turnover in the part-time work context. Career Development International, 6, 39-47. https://doi.org/10.1108/13620430110381025

Meyer, J. P., Allen, N. J., \& Smith, C. A. (1993). Commitment to organizations and occupations: Extension and test of a three-component conceptualization. Journal of Applied Psychology, 78, 538-551. https://doi.org/10.1037/0021-9010.78.4.538

Michaels, C. E., \& Spector, P. E. (1982). Causes of employee turnover: A test of the Mobley, Griffeth, Hand and Meglino model. Journal of Applied Psychology, 67, 53-59. 
https://doi.org/10.1037/0021-9010.67.1.53

Miller, L. E., Powell, G. N., \& Seltzer, J. (1990). Determinants of turnover among volunteers. Human relations, 43, 901-917. https://doi.org/10.1177/001872679004300906

Mobley, W. H. (1982). Employee turnover: Causes, consequences and control. Reading, MA: Addison-Wesley.

Mobley, W. H., Griffeth, R. H., Hand, H. H., \& Meglino, B. M. (1979). Review and conceptual analysis of the employee turnover process. Psychological Bulletin, 86, 493-522. https://doi.org/10.1037/0033-2909.86.3.493

Mobley, W. H., Horner, S. O., \& Hollingsworth, A. T. (1978). An evaluation of precursors of hospital employee turnover. Journal of Applied Psychology, 63, 408-414. https://doi.org/10.1037/0021-9010.63.4.408

Moore, J. E. (2000). One road to turnover: An examination of work exhaustion in technology professionals. MIS Quarterly, 34, 141-168. https://doi.org/10.2307/3250982

Mowday, R. T., Porter, L. M., \& Steers, R. M. (1982). Employee-organizational linkage: The psychology of commitment, absenteeism, and turnover. New York, NY: Academic Press.

Moynihan, D. P., \& Landuyt, N. (2008). Explaining turnover intention in the public sector: Examining the roles of gender, life cycle and loyalty. Review of Public Personnel Administration, 28, 120-143. https://doi.org/10.1177/0734371X08315771

Muchinsky, P. M., \& Morrow, P. C. (1980). Multidisciplinary model of voluntary employee turnover. Journal of Vocational Behavior, 17, 263-290. https://doi.org/10.1016/0001-8791(80)90022-6

Niederman, F., \& Sumner, M. (2001). Job turnover among MIS professionals: An exploratory research of employee turnover. In M. Serva (Ed.), Proceedings of the 2001 ACM SIGCPR Conference on Computer Personnel Research (pp. 11-20). New York, NY: Association for Computer Machinery. https://doi.org/10.1145/371209.371210

O'Reilly, C. A., Chatman, J. A., \& Caldwell, D. F. (1991). People and organizational culture: A profile comparison approach to assessing person-organization fit. Academy of Management Journal, 34, 487-516. https://doi.org/10.2307/256404

Panigyrakis, G. (2009). Internal marketing impact on business performance in a retail context. International Journal of Retail \& Distribution Management, 37, 600-628. https://doi.org/10.1108/09590550910964620

Paré, G., \& Tremblay. M. (2007). The influence of high-involvement human resources practices, procedural justice, organizational commitment, and citizenship behaviors on information technology professionals' turnover intentions. Group \& Organization Management, 32(3), 326-57. https://doi.org/10.1177/1059601106286875

Pearce, J. L. (1983) Participation in voluntary associations: How membership in a formal organization changes the rewards of participation. In D. H. Smith, J. Van Til, V. Pestoff \& D. 


\section{MInstitute Machink $_{\text {Inthe }}$}

International Journal of Human Resource Studies

ISSN 2162-3058 2018, Vol. 8, No. 1

Zeldin (Eds.), International perspectives in voluntary action research (pp. 148-156). Washington, DC: University Press of America.

Pelled, L. H., \& Xin, K. R. (1999). Down and out: An investigation of the relationship between mood and employee withdrawal. Journal of Management, 25, 875-895. https://doi.org/10.1177/014920639902500605

Peltokorpi, V., Allen, D. G., \& Froese, F. (2015) Organizational embeddedness, turnover intentions, and voluntary turnover: the moderating effects of employee demographic characteristics and value orientations, Journal of Organizational Behavior, 36(2), 292-312. https://doi.org/10.1002/job.1981

Podsakoff, P. M., MacKenzie, S. B., Lee, J. Y., \& Podsakoff, N. P. (2003). Common method biases in behavioral research: A critical review of the literature and recommended remedies. Journal of Applied Psychology, 88, 879-903. https://doi.org/10.1037/0021-9010.88.5.879

Porter, L. W., Steers, R. M., Mowday, R. T., \& Boulian, P. V. (1974). Organizational commitment, job satisfaction, and turnover among psychiatric technicians. Journal of Applied Psychology, 59, 603-609. https://doi.org/10.1037/h0037335

Prasad, A., \& Steffes, E. (2002). Internal marketing at Continental Airlines: Convincing employees that management knows best. Marketing Letters, 13, 75-89. https://doi.org/10.1023/A:1016009201552

Preacher, K. J., \& Hayes, A. F. (2008). Asymptotic and resembling strategies for assessing and comparing indirect effects in multiple mediator models. Behavior Research Methods, 40, 879-891. https://doi.org/10.3758/BRM.40.3.879

Price, J. L. (2001). Reflections on the determinants of voluntary turnover. International Journal of Manpower, 22, 600-675. https://doi.org/10.1108/EUM6233

Ravlin, E. C., \& Meglino, B. M. (1987). Effects of values on perception and decision making: A study of alternative work values measures. Journal of Applied Psychology, 72, 666-673. https://doi.org/10.1037/0021-9010.72.4.666

Rhodes, S. R., \& Steers, R. M. (1990). Managing employee absenteeism. Reading, MA: Addison-Wesley.

Rokeach, M. (1973). The nature of human values. New York, NY: Free Press.

Rubenstein, A. L., Marion, E. B., T.w., Lee L., and\& Mitchell, T. (2017). Surveying the forest: Ameta-analysis, moderator investigation, and future-oriented discussion of the antecedents of voluntary employee turnover. Personnel psychology, 7(1), 23-65. https://doi.org/10.1111/peps.12226

Sagie, A., Elizur, D., \& Koslowsky, M. (1996). Work values: A theoretical overview and model of their effects. Journal of Organizational Behavior, 17, 503-514. https://doi.org/10.1002/(SICI)1099-1379(199612)17:1+<503::AID-JOB820>3.0.CO;2-Q

Schlessenger, L. A., \& Heskett, J. L. (1991). Breaking the cycle of failure in services. Sloan 
Management Review, 32(3), 17-28.

Schultz, D. E. (2004). Building an internal marketing management calculus. Interactive marketing, 6(2), 111-129. DOI:10.1057/palgrave.im.4340276

Schwab, D. N. (1991). Contextual variables in employee performance-turnover relationships. Academy of Management Journal, 34, 966-975. https://doi.org/10.2307/256400

Schwartz, S. H. (2006). Les valeurs de base de la personne: Théorie, mesures et applications [Basic human values: Theory, measurement, and applications]. Revue Française de Sociologie, 47, 249-288. https://doi.org/10.3917/rfs.474.0929

Shore, L. M., \& Martin, H. (1989). Job satisfaction and organizational commitment in relation to work performance and turnover intentions. Human relations, 42, 625-638. https://doi.org/10.1177/001872678904200705

Shrout, P. E., \& Niall, B. (2002). Mediation in experimental and non experimental studies: New procedures and recommendations. Psychological Methods, 7, 422-445. https://doi.org/10.1037/1082-989X.7.4.422

Starnes, B. J., \& Wymer, W. W. (2001). Conceptual foundations and practical guidelines for retaining volunteers who serve in local not-for-profit organizations. Journal of Nonprofit and Public Sector Marketing, 9, 97-118. https://doi.org/10.1300/J054v09n01_06

Steel, R. P., \& Ovalle, N. K. (1984). A review and meta-analysis of research on the relationship between behavioral intentions and employee turnover. Journal of Applied Psychology, 69, 673-686. https://doi.org/10.1037/0021-9010.69.4.673

Tansuhaj, P., Randall D., \& McCullough, J. (1991). Applying the internal marketing concept within large organizations: As applied to a credit union. Journal of Professional Services Marketing, 6, 193-202. https://doi.org/10.1300/J090v06n02_14

Tett, R. P., \& Meyer, J. P. (1993). Job satisfaction, organizational commitment, turnover intention and turnover: Path analyses based on meta-analytic findings. Personnel Psychology, 46, 259-293. https://doi.org/10.1111/j.1744-6570.1993.tb00874.x

Timmerman, T. A., Barger, B., Elsawy, A., \& Mahmoud, W. (2003, June). Managing virtual teams in senior industrial projects. Paper presented at the American Society for Engineering Education Annual Conference And Exposition, Nashville, TN.

Van Dick, R. (2001). Identification in organizational contexts: Linking theory and research from social and organizational psychology. International Journal of Management Reviews, 3, 265-283. https://doi.org/10.1111/1468-2370.00068

Vasconcelos, A. F. (2011). Internal demarketing: Construct, propositions, and managerial implications. Marketing \& Management, 6(1), 35-58.

Vroom, V. H. (1966). Organizational choice: A study of pre- and post decision processes. Organizational Behavior and Human Performance, 1, 212-225. https://doi.org/10.1016/0030-5073(66)90013-4 


\section{Macrothink}

International Journal of Human Resource Studies

ISSN 2162-3058 2018, Vol. 8, No. 1

Wagner, A. K. (2011). Common methods bias: Part 2: Marketing research. In Wiley international encyclopedia of marketing. https://doi.org/10.1002/9781444316568.wiem02033.

Wang, C. P. (2002). The relationship between internal marketing practice, satisfaction, and employee turnover intension: A case study of chain entertainment business (Unpublished master's thesis). National Sun Yat-Sen University, Kaohsiung, Taiwan.

Wanxian, L, W., \& Xinmei, L. (2007). Demographic effects of work values and theirmanagement implications. Journal of Business Ethics, 81, 875-885. DOI $10.1007 / \mathrm{s} 10551-00-9554-6$

Way, S. A. (2002). High performance work systems and intermediate indicators of firm performance within the US small business sector. Journal of Management, 28, 765-785. https://doi.org/10.1016/S0149-2063(02)00191-5

Wilson, N., \& Peel, M. J. (1991). The impact on absenteeism and quits of profit-sharing and other forms of employee participation. Industrial and Labor Relations Review, 44, 454-468. https://doi.org/10.1177/001979399104400304

Woodruff, R. B. (1997). Customer value: The next source of competitive advantage. Journal of the Academy of Marketing Science, 25, 153-139139-153. https://doi.org/10.1007/BF02894350

Yang, K., \& Pandey, S. (2009). How do perceived political environment and administrative reform affect employee commitment? Journal of Public Administration Research and Theory, 19, 335-360. https://doi.org/10.1093/jopart/mun002

You, M. S. (2004). A study on the relationships among internal marketing, job satisfaction, and turnover intention in international tourist hotel - in Taipei case (Unpublished master's thesis). Ming-Cuang University, Taipei, Taiwan.

\section{Copyright Disclaimer}

Copyright for this article is retained by the author(s), with first publication rights granted to the journal.

This is an open-access article distributed under the terms and conditions of the Creative Commons Attribution license (http://creativecommons.org/licenses/by/4.0/). 